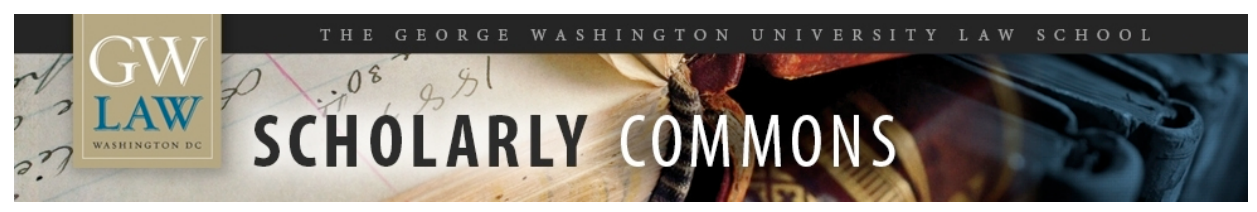

\title{
Beyond Retribution and Impunity: Responding to War Crimes of Sexual Violence
}

Naomi R. Cahn

George Washington University Law School, ncahn@law.gwu.edu

Follow this and additional works at: https://scholarship.law.gwu.edu/faculty_publications

Part of the Law Commons

\section{Recommended Citation}

Cahn, Naomi R., "Beyond Retribution and Impunity: Responding to War Crimes of Sexual Violence" (2004). GW Law Faculty Publications \& Other Works. 332.

https://scholarship.law.gwu.edu/faculty_publications/332

This Article is brought to you for free and open access by the Faculty Scholarship at Scholarly Commons. It has been accepted for inclusion in GW Law Faculty Publications \& Other Works by an authorized administrator of Scholarly Commons. For more information, please contact spagel@law.gwu.edu. 


\title{
Beyond Retribution and Impunity: Responding to War Crimes of Sexual Violence
}

\author{
Naomi Cahn*
}

Over the past five years, as many as 100,000 Congolese women, girls, and babies

have been subjected to gender-based violence. Like the other human rights crimes that

occurred during the Congolese "civil" war ${ }^{1}$, gender-based violence is both an individual

and a community abuse. ${ }^{2}$ As the Congo begins to emerge from this conflict, the

questions here, as in other countries that have confronted these issues, center on

impunity, prosecution, and reconciliation. The standard human rights non-governmental

organization response seems to be to investigate and prosecute, to end the impunity that

has protected human rights abusers in this country for so long. ${ }^{3}$ Other non-governmental

organizations and some of the international organizations are more focused on issues of

\footnotetext{
* Professor of Law, George Washington University (on leave, 2002-2004). The author has been living in Kinshasa, Democratic Republic of the Congo since July 2002. Many thanks to Colleen Duggan, Elfia Elesse, Mary-Louise Eagleton, Tony Gambino, C. Quince Hopkins, and Jo Wells for comments and support; and to Terra Nevitt and Alyson Thomas for research assistance.

1 The abuses during the war have been so egregious that Luis Moreno-Ocampo, the Chief Prosecutor of the newly established International Criminal Court in The Hague stated that he has "selected the situation in Ituri (DRC) as the first situation which merits to be closely followed by the office." Statement of the Prosecutor at the Second Assembly of States Parties to the Rome Statute of the International Criminal Court 2 (Sept. 8, 2003), available at http://www.icc-cpi.int/library/organs/otp/030909 prosecutor_speech.pdf. The first two cases selected for investigation by the ICC involve the Congo and Uganda. ICC assigns cases on DR of Congo, northern Uganda to pre-trial chambers, July 7, 2004(avail. at http://www.un.org/esa/africa/UNNews_Africa/ICC.htm).

2 Gender-based violence is committed against individuals or groups on the basis of gender or sex, and includes rape, sexual slavery, sexual abuse, forced pregnancy, and threats of such acts. See, e.g., UNHCR, Sexual and Gender-Based Violence Against Refugees, Returnees and Internally Displaced Persons:

Guidelines for Prevention and Response, 10 (2003); Reproductive Health Response in Conflict Consortium, Gender-Based Violence Tools Manual for Assessment \& Program Design, Monitoring \& Evaluation in Conflict-Affected Areas, 13-14 (2004) .

${ }^{3}$ E,g., Amnesty International, Democratic Republic of Congo: No peace without an end to impunity for human rights abuses, Oct. 24, 2003, available at http://web.amnesty.org/library/Index/ENGAFR620472003?open\&of=ENG-COD; Irene Khan's closing statement for Amnesty International's high level mission to the Great Lakes' region, available at http://web.amnesty.org/library/Index/ENGAFR010102003?open\&of=ENG-COD (“Our second recommendation is that those who are suspected of having perpetrated war crimes, crimes against humanity and genocide must be investigated and brought to justice").
} 
demobilization and reintegration, even if the people being reintegrated are those whom the human rights non-governmental organizations would prefer to see prosecuted for their role in committing violence against women and other atrocities during the conflict.

Conflicts affect both men and women, but women face additional issues during wars that men do not, including, of course, sexual violence, forced impregnation, or forced abortion. ${ }^{4}$ The recent conflicts in Rwanda and the former Yugoslavia illustrate the impact of rape and displacement on women. Women are also differentially affected because of their role as the primary caretaker of the household and family, and because of their legally-enforced second class status in most conflict zones. In any discussion of sexual violence, it is critical to focus on women's status as well. ${ }^{5}$ While this article examines issues of sexual violence, it discusses practices for dealing with such violence that also implicate the other impacts of armed conflict on women.

Now that sexual violence is considered a war crime, and can be prosecuted as such in international courts, ${ }^{6}$ how can we think about responding to crimes of sexual violence in the context of the Congolese war and of the ensuing agreement to make the transition to a democratic government? Is prosecution appropriate? A truth-and-

\footnotetext{
${ }^{4}$ See Hilary Charlesworth, Feminist Methods in International Law, 93 AM. J. INTL. L. 379, 385 (1999). Some sexual violence during conflicts is committed against boys and men, but the overwhelming majority is committed against women and girls. See Kelly D. Askin, Prosecuting Wartime Rape and other GenderRelated Crimes under International Law: Extraordinary Advances, Enduring Obstacles, 21 BERKELEY J. INT'L L. 288, 297 (2003) (other than sexual violence in prisons, sex crimes are committed "overwhelming[ly]" against women). Homosexual rape has been credibly reported in the Congo, but is far less common that heterosexual rape.

${ }^{5}$ See Charlesworth, supra, at 388 (there is a "silence ... in the legal protection of the human rights of women in armed conflict [due to] the almost exclusive focus on sexual violence"); Human Rights Watch, Shattered Lives: Sexual Violence during the Rwandan Genocide and its Aftermath (1996).

${ }^{6}$ E.g., Prosecutor v. Akayesu, Judgement, No. 96-4-T (Sept. 2, 1998)(www.un.org/ictr); Rome Statue of the International Criminal Court, July 17, 1998, art. 7(2)(e), U.N. Doc. A/CONF.183/9*; Kristen Boon, Rape and Forced Pregnancy under the ICC Statute, 32 Colum. Human Rts. L. Rev. 625 (2001).
} 
reconciliation commission? A restorative justice approach? ${ }^{7}$ Other non-confrontational methods? Remedies, or retribution, or reparation for wrongdoing occur in the context of the delicate development of democracy. With a fragile, barely functioning, internal justice system, a coalition government that requires thousands of UN troops to patrol the streets to maintain peace and that depends on outside donors for operating expenses, with members of the government possibly indictable for war crimes for their involvement in the civil war, the Congo faces difficult questions in deciding how to handle sexual violence.

In its broader context, these issues challenge conventional notions concerning the role, and rule, of law in conflict situations. For those of us trained to think in terms of legal solutions, of justice via international, regional, or local tribunals, of prosecutions and investigations and evidence and trials, these concepts must be tested in countries with no functioning justice system, with no means of protecting victim-witnesses, and with only minimal assurance that genocide and gender-based violence will not recur. In these countries, we must be particularly sensitive to what role the law can and should play in ending impunity and restoring confidence that the war wounds can be healed. Finding justice for victims and punishing perpetrators are critical, but there are important contextual issues on how best to proceed to ensure that these occur as countries struggle to establish new governments. In our focus on legal approaches, we must remember the practical realities that confront victims of gender-based violence as they continue with their lives, often living in the same communities as the perpetrators, and thus craft

\footnotetext{
7 See Martha Minow, Between Vengeance and Forgiveness: Feminist Responses to Valence Injustice, 32 New EngL. L. REV. 967, 970, 974 (1998); C. Quince Hopkins, et al., Applying Restorative Justice to Ongoing Intimate Violence: Problems and Possibilities, 23 ST. LOUIS U. PUB. L. REV. _ (forthcoming 2004).(manuscript at_, on file with author)
} 
remedies that account for these differing, potentially conflicting, realities which themselves may reflect divergent constituencies: a need for punishment, a need for rehabilitation for both victims and perpetrators, and a need for national reconciliation.

While issues in transitional countries challenge the rule and role of law, they also raise critical issues concerning victimization. Women who have been subjected to sexual violence by armed groups are certainly victims ${ }^{8}$, yet they are often scorned and treated by their families and communities as outcasts, while the soldiers who committed the crimes are welcomed home. This treatment of women stems from two different causes: first, women's status in many developing countries is quite low, and women are not given the same rights as men, nor do they receive the same respect; a second reason, intertwined with the first, is that while sexual violence is slowly being accepted by the international community as a crime, it still is not treated as seriously as other war crimes. In the Congo, impunity has been total, with no punishments for the wide-scale war crimes. ${ }^{9}$

This article articulates principles for a victim-centered approach to gender-based violence during conflict and post-conflict that operates within three different meanings of justice: criminal/civil justice, restorative justice, and what I will refer to as social

\footnotetext{
${ }^{8}$ They are also survivors, and there has been much discussion over whether to label them victims or survivors. Kelly D. Askin, The Quest for Post-Conflict Gender Justice, 41 ColuM. J. TransN'L L. 509, 515 (2003); see also Leigh Goodmark \& Catherine F. Klein, Deconstructing Teresa O'Brien: A Role Play for Domestic Violence Clinics, 23 ST. Louis U. PuB. L. REV. 253, 285 (2004) and Carolyne R. Dilgard, Note, Crossing the Line: The Interstate Implications of Issuing and Enforcing Domestic Violence Protection Orders: An Examination of New Jersey, 35 RUTGERS L.J. 253, n.7 (2003).

Some of the humanitarian organizations use the term survivor because victim "connotes powerlessness and stigma" rather than the "strength and resilience" associated with "survivor." Vann, supra note _, at v. I use the terms interchangeably, because the women are both victims and survivors. ${ }^{9}$ This may be changing with the ICC initiative. See supra $n .1$.

In addition to physical crimes, the Congo has also experienced economic crime on a large-scale level, with plundering of the Congo's rich natural resources. Notwithstanding a UN report on the situation, the perpetrators have not been disciplined. See Naomi Cahn, Corporate Governance Divergence and SubSaharan Africa: Lessons from Out Here in the Fields, 33 STETSON L. Rev. 893, 906 (2004) (discussing UN Panel report).
} 
services justice. ${ }^{10}$ This project requires, as a first principle, simply listening to what individual victims want and need. This first step involves hearing and recording their stories and identifying the various consequences in their lives of the violence. Because violence affects so many parts of the victims' lives, the second principle requires looking both within the law and outside of the law in the effort to develop appropriate responses. Victims may seek civil or criminal sanctions against their perpetrators, but they may also need seeds to replace those that we pillaged so that they can grow food for their families, more efficient stoves so that they don't need to go into the forests, where they are susceptible to attack, less frequently to collect wood, or whistles so that they can call for help if they are attacked. Legal responses are often inadequate, undesirable, or untenable. Responses to sexual violence must integrate legal and nonlegal, national, international, and local approaches, and must respond to both short and longer-term needs.

The third and final principle, however, requires placing individual victims, who may have been raped, penetrated with guns or sticks or knives or machetes, into the larger contexts of their families, communities, and country. Each victim of gender-based violence deserves justice, but that justice must be defined by more than individual needs. Rape during armed conflict is both an individual and a group harm, a crime against the person and against her community and her gender by a perpetrator or group of perpetrators. This final principle requires going beyond the victim and placing her within her differing communities; in turn, appropriate responses requires balancing what the

\footnotetext{
10 "Social service justice" provides another dimension to concepts of justice by focusing on the social, economic, medical, and psychological components of providing justice to victims. While this may be a component of restorative justice, which seeks reintegration of the perpetrator and victim into their communities, social services justice is a broader concept. The standard dictionary definition of "justice" focuses on doing what is right and fair, and the administration of legal process is only one of multiple definitions.
} 
victim wants, what is in her best interests, and what is in the best interests of her larger communities.

A critical issue for non-traditional justice approaches is ensuring responsibility and accountability of perpetrators while also serving the needs of victims. When justice includes what might be characterized as "development” services, such as different forms of direct aid to recipients, these services cannot be separated from perpetrator responsibility. The focus of the traditional criminal justice system is almost solely on the perpetrator; indeed, the victim is not a party to the proceedings but is called as a witness by the prosecution, who represents the public interest. ${ }^{11}$ Alternative forms of justice have broadened this focus, recognizing that the legal system must respond to both victims and perpetrators. It is by listening to victims, responding to their needs in concrete ways, and placing the victim within her larger community that we can craft responses to crimes of mass violence that respect what the victim has undergone, punish the perpetrator, and provide lessons to the public on the utter revulsion with which the underlying conduct must be treated. Individual justice is critical, but large-scale crimes are symptomatic of other serious problems in the surrounding culture. Transitional justice, which focuses on responding to past official violations of human rights, is critical to holding violators accountable for their acts. ${ }^{12}$

\footnotetext{
${ }^{11}$ Of course, this shows the perpetrator that the crime was committed against society, and relieves pressure on the victim. See Hopkins, Applying Restorative Justice, supra note _, at 2 ("as witnesses rather than parties in criminal cases, victims' control over prosecution is limited; in fact, the traditional criminal justice system, at the urging of battered women's advocates, affirmatively displaces battered women . . . in a noble effort to take on primary responsibility of confronting batterers about their violence"); Joan Meier, The "Right" to a Disinterested Prosecutor of Criminal Contempt: Unpacking Public and Private Interests, 70 Wash. U. L.Q. 85 (1992) Nancy Rosenblum, supra note _, at 88 ("legal proceedings in response to human rights violations have as their goal justice and not assistance to the aggrieved”).

12 See Ruti Teitel, Transitional Justice (2000); The Future of Human Rights Discourse, 46 St.Louis L.J. 449, 449, 451 (2002).
} 
This article proceeds by discussing the contemporary Congolese conflict, providing the context for the sexual violence that has occurred over the past eight years. ${ }^{13}$ Next, the article provides a fuller development of the principles that should guide any response to the sexual violence, surveying the possible approaches. The continuum of current approaches ranges from attempted prosecution of all perpetrators to a focus on elections and reintegration of both victims and former soldiers. Finally, the article provides specific recommendations for a victim-centered approach that also reflects and respects community concerns and interests. The relationship between sexual violence, retribution, and reconciliation is a new topic that is just beginning to be studied, and the Congo provides a topical forum for discussing these issues.

I. The Conflict

This section explores the background to the Congolese conflict, before discussing the impact of sexual violence against women. The impact ranges from the actual physical harms to economic harms to health harms; although the rate of HIV-AIDS is approximately 6-7\% nationwide, it is estimated to be much higher in the conflict zones. ${ }^{14}$

13 There are several possible dates for the beginning of the conflict. See infra $\mathrm{nn}$. _.

When the war in the Congo receives scholarly attention, the focus is generally on issues of conflict diamonds. See e.g. Julia Graff, Corporate War Criminals and the International Criminal Court: Blood and Profits in the Democratic Republic of Congo, 11 HUM. RTS. BRIEF 23 (2004) (discussing the possibility of holding corporate actors of companies involved in the diamond trade criminally responsible for their financial involvement in Congo's conflict); Margo Kaplan, Carats and Sticks: Pursuing War and Peace Through the Diamond Trade, 35 N.Y.U. J. INT’L L. \& PoL. 559, 560, 578-580 (2003) (citing the war in Congo as a notorious example of a conflict fueled by "greed and pillage”); Daniel L. Feldman, Conflict Diamonds, International Trade Regulation, and the Nature of Law, 24 U. PA. J. INT'L ECON. L. 835, 835 (2003) ("Conflict diamonds both financed and motivated vicious terrorist organizations in Sierra Leone, Angola, and the Congo.”), Tracey Michelle Price, The Kimberley Process: Conflict Diamonds, WTO Obligations, and the Universality Debate, 12 MinN. J. GLOBAL TRADE 1, 16-21 (2003) ("Diamonds from Angola, Sierra Leone, and the ... (DRC), in particular, have fuelled rebellion and human rights violations for at least a decade.”).

${ }^{14}$ For rape survivors in eastern Congo, the rate is estimated to be over 25\%. Pratt and Werchick, at 12; see infra nn. 
The Congolese “civil war” has been labeled Africa's "first world war” and categorized as the worst world conflict since the Second World War. ${ }^{15}$ The Congo, which is about the size of the United States east of the Mississippi River, is a country rich in natural resources. ${ }^{16}$ It exports diamonds, cobalt, copper, coffee, and oil, and has vast deposits of coltan, a critical component of cell phones and other technological equipment. But the country has a long history of corruption. When Portuguese first found the Congo River, in the late fifteenth century, they sent out teachers and masons - but these men abandoned their professions and entered the far more lucrative slave-trade. ${ }^{17}$ In 1885 , at the Berlin Conference where Europeans met to carve out territories in Africa for themselves, King Leopold of Belgium seized the Congo for his own self gain and glory. ${ }^{18}$ Although Leopold claimed that he had established a free trade zone in the country, which exported rubber and ivory, he was instead exploiting the country, treating it as a privately-owned slave colony from which Leopold was underreporting profits and pocketing the rest. ${ }^{19}$ When Belgium granted independence to the Congo, in 1960, there were fewer than 30 Congolese who had graduated from university and, among the 5,000 management-level positions in the government, there were only three held by Congolese. ${ }^{20}$ In 1965, Joseph Desire Mobutu, who had received payments from the CIA,

\footnotetext{
15 “Congo's war [is] the worst anywhere since the second world war." Making Africa Smile, THE ECONOMIST, Jan 17, 2004.

16 For a history of private sector irresponsibility, see ADAM HoCHSCHILD, KING LEOPOLD’s GHOST: A STORY OF GREED, TERROR, AND HEROISM IN COLONIAL AFRICA (1999); for a fictionalized account, see JOSEPH CONRAD, HEART OF DARKNESS (__ $)$.

17 HochSCHILD, supra note _, at 10

18 HochsCHILD, supra note _, at 84-87.

19 Id. at 158, 179-80.

20 HochsCHILD, supra note _, at 301.
} 
mounted a coup to become the head of the country. It is an understatement to note that corruption and human rights abuses continued during the 32 years that he was dictator. ${ }^{21}$

There is not one specific origin for the recent war, but the catalyst was the Rwandan genocide of 1994, in which the Hutu -led Rwandan government organized mass killings of hundreds of thousands of Rwandan Tutsis and moderate Hutus. ${ }^{22}$ After its defeat, the government and military forces fled to neighboring Congo (called Zaire at that point). ${ }^{23}$ In 1996, the now Tutsi-led Rwandan government sent troops over the border into the Congo, claiming that it needed to protect Rwandan Tutsis against further slaughter. Rwandans, together with a local coalition led by Laurent Kabila, the AFDL (Alliance des Force Democratiques pour la Liberation du Congo-Zaire), attacked the Rwandan refugee camps in eastern Congo, killing tens of thousands, primarily civilians. Uganda then sent soldiers in support of the AFDL. With Kabila as the leader, the Rwandans, Ugandans, and AFDL overthrew Mobutu in May, 1997.

During the summer of 1998, Kabila tried to free himself from the Rwandans and Ugandans, and the current war started on August 2. The Rwandans and Ugandans formed a coalition with the Rally for Congolese Democracy (RCD) to oust Kabila. Kabila, in turn sought help from Zimbabwe, Angola, and Namibia. Although there was a cease-fire accord in July 1999, the fighting continued, and the country was essentially divided into three parts, one controlled by the Kinshasa-based government, one by the

21 Michaela Wrong, In The Footsteps of Mr. Kurtz: Living on the Brink of Disaster in Mobutu’s Congo (200).

${ }^{22}$ For descriptions of the genocide, see PhILIP GOUREVITCH, WE Wish TO INFORM YOU THAT TOMORROW We Will Be Killed With OuR FAMilies: StORIES FROM RWANDA (1998); AlisOn Des Forges, LEAVE None to Tell THE STORY”: GenOCIDE In RWANDA (1999); Mark Drumbl,

The roots of the 1994 genocide are themselves complex. See Africa Watch: Rwanda: Talking Peace and Waging War: Human Rights since the October 1990 Invasion (1992); Filip Reyntjens, Rwanda, Then Years on: From Genocide to Dictatorship, 103 AfRICA AFFAIRS 177, 194, 204 (2004). 
RCD, and a third by the Congolese Liberation Movement (MLC), supported by Uganda. ${ }^{24}$ Funding for all sides of the civil war came from the illegal exploitation of Congo's natural resources, particularly gold and diamonds, ${ }^{25}$ but also coltan, cobalt, and timber. ${ }^{26}$ Indeed, so egregious were the abuses of natural resources that the United Nations issued a special report that recommended that 29 companies be subjected to financial restrictions, including a freezing of assets and a suspension of banking abilities. $^{27}$

In January 2001, Kabila was assassinated by a bodyguard, and his son Joseph became president. Shortly thereafter, the UN strengthened its peace-keeping mission (MONUC, the UN Observation Mission in the Congo), which was supposed to supervise the cease-fire and subsequent demobilization. The MONUC mandate was limited, and fighting continued in the six provinces in the eastern part of the country. Additional peace negotiations continued, and the various rebel groups and countries which had sent in troops signed additional accords. With the withdrawal of foreign troops, however, local militias continued to fight, rape, and massacre people in the East. ${ }^{28}$ And, although Rwanda's official withdrawal from the Congo catalyzed the creation of the transition

23 Des Forges; Human Rights Watch, Shattered Lives: Sexual Violence during the Rwandan Genocide and its Aftermath (1996)(avail. at http://www.hrw.org/reports/1996/Rwanda.htm).

${ }^{24}$ Keith Somerville, DR Congo Awash with Rebels, BBC NEws ONLINE, July 23, 2002 (available at http://news.bbc.co.uk/1/hi/world/africa/2146537.stm).

${ }^{25}$ United NATIONS, FinAL REPORT OF THE PANEL OF EXPERTS ON THE ILLEGAL EXPLOITATION OF Natural Resources and Other Forms of Wealth of the Democratic Republic of the Congo, 1415, S/2003/1027, Oct. 23, 2003.

${ }^{26}$ E.g., Jonathan M. Winer and Trifin J. Roule, Follow the Money: The Finance of Illicit Resource Extraction, in NRVC, supra note _, 161, 201.

${ }_{27}$ See 2002 UN Report, supra note

${ }^{28}$ BBC News, Timeline: Democratic Republic of the Congo, Sept. 4, 2003 (available at http://news.bbc.co.uk/1/hi/world/africa/1072684.stm). 
government, the Rwandan army has nonetheless continued to intervene in the Eastern Congo. $^{29}$

Today, the country may be emerging from the long civil war ${ }^{30}$, which has had a death toll of more than 3 million of the 50-60 million people in the Congo, including soldiers and civilians who died from starvation and disease. ${ }^{31}$ The current president, Joseph Kabila, has agreed to hold elections within the next several years. There are 4 vicepresidents representing the differing former combatant parties as well as the nascent political parties, ${ }^{32}$ and thousands of peace-keepers from the United Nations throughout the country. Nonetheless, fighting continues in the eastern part of the country, and civilians are still being raped and murdered.

b. Women's Status in the Congo

Rape is such an effective weapon of war because it affects the women, their families, and their communities. Its effectiveness, however, also depends on its ability to bring together the “'c concepts of honor, shame and sexuality that are attached to women’s bodies in peacetime.”,33 Because rape is also seen as a crime against a family’s honor,

\footnotetext{
29 See REYNTJENS, supra note _, at 207-208. Reyntjens criticizes the current Rwandan government for capitalizing on a "genocide credit" and continuing to destabilize the regions by fighting its enemies outside its own borders. Id. at 204, 207.

${ }^{30}$ International Rescue Committee, Mortality in the Democratic Republic of the Congo: Results from a National Survey 6 (April 2003)(available at http://intranet.theirc.org/docs/drc_mortality_iii_report.pdf.) Although sometimes labeled a civil war, the Congolese conflict actually involves many neighboring countries which have provided support to various factions, and which themselves have fought battles on Congolese territory.

${ }^{31}$ For details on some of the atrocities committed, see, e.g., Final Report of the Panel of Experts on the Illegal Exploitation of Natural Resources and Other forms of Wealth in the Democratic Republic of the Congo, S/2002/1146, United Nations, Oct. 16, 2002; Daniel Bergner, The Most Unconventional Weapon, N.Y. Times, Oct. 26, 2003, at Sec. 6, p. 48.

32 See, e.g., Marc Lacey, Hope Glimmering as War Retreats from Congo, N.Y. TIMES, Oct. 21, 2003, at A1.

${ }^{33}$ Therese McGinn, Reproductive Health of War-Affected Populations: What do We Know?, 26 FAM. PlANNING PERSPECTIVES, Dec. 2000, at 11 (quoting comment about wartime rape in the former Yugoslavia)(available at http://www.guttmacher.org/pubs/journal/2617400.html).
} 
combatants' use of sexual violence has broad effects beyond the victim herself. ${ }^{34}$ In the Congo, as in many other countries that have experienced conflict, women are legally subordinate to men, and the use of rape during the conflict exacerbated women's secondclass status.

The Congo has signed the Convention on the Rights of the Child and the Convention on the Elimination of All Forms of Discrimination Against Women (CEDAW). ${ }^{35}$ Notwithstanding guarantees of equality for men and women in these documents, women's inequality in the Congo is codified in various laws left over from Belgian colonial rule. The Congo has yet to develop a women's rights movement on a large scale, although there are small groups of women’s organizations. Girls can get married at age 15 without parental permission, although boys must wait until $18 .{ }^{36}$ A man and his family are required to pay a dowry for his bride before a marriage can occur. $^{37}$ The Family Code explicitly designates the husband as the head of the Congolese family, and requires the wife to defer to her husband's decisions (unless she

\footnotetext{
${ }^{34}$ In War as in Peace, supra note _, at 2.

35 See War Within a War, at 89-90 (Congo is a party to the International Covenant on Civil and Political Rights, the Convention Against Torture and Other Cruel Inhuman and Degrading Treatment of Punishment, the Convention on the Rights of the Child, the African Charter on Human and Peoples' Rights, and CEDAW)

36 Code de la Famille art. 352. All translations are the author's own.

Although there have been attempts to place Congolese laws on the internet, see juricongo.net, they have not yet been entirely successful, and the laws are generally compiled in loose-leaf pamphlets, sometimes by non-governmental organizations. To those of us comfortable in legal research on US law, the system feels antiquated and somewhat suspect. See also Stuart Cohn, Teaching in a Developing Country: Mistakes Made and Lessons Learned in Uganda, 48 J. LEGAL EDUC. 101, (1998). In preparing to teach a specialized course on securities markets in Uganda, Professor Cohn discovered that "Nothing existed except the laws, a Capital Markets Authority that had no capital markets to regulate, and a stock exchange devoid of stock.” Id. at 104. His advice to other teacher developing similar courses is not to assume that their students know the law; In Uganda, for example, copies of relevant statutes were simply not available in the numbers necessary for teaching in the classroom. Id. at 108.

37 Art. 361. The dowry can be symbolic, but at least something must be exchanged before the marriage can be celebrated. Id. In some tribes, when a sister marries, the money received for her dowry is used to pay for her brother's wife.
} 
sues him). ${ }^{38}$ The Family Code requires that a woman obtain her husband's permission before undertaking any legal act, ${ }^{39}$ and warns, in the same provision establishing the incapacity of minors and those who are mentally incompetent, that wives' capacities may be limited in accordance with the law. ${ }^{40}$ Only in 2002 was the Labor Code changed to allow a wife to work without her husband's permission. A woman must live with her husband and follow him where he thinks it appropriate to reside. ${ }^{41}$ If there is a disagreement between the mother and the father concerning childrearing, the father's decision controls. ${ }^{42}$ Abortion is illegal, and the laws on contraception and women’s status have been interpreted to require that a woman obtain her husband's permission before obtaining birth control. ${ }^{43}$

The laws on rape, which are rarely enforced, date back to the early twentieth century Belgian colonial penal code, with minor modifications since then. Rape is addressed in a section that is titled "infractions against the proper family order," and the law addresses two different kinds of sexual crimes: first, a violation of modesty committed with violence, cunning, or threat by one person to another of the opposite sex is punishable by imprisonment of between six months and five years, and second, a rape, with the aid of violence or serious threat or cunning is punishable by imprisonment of

\footnotetext{
38 Art. 444 of the Code de law Famille states : « Le mari est le chef du menage. Il doit protection a sa femme ; la femme doit obeissance a son mari.

39 Art. 448, Code de la Famille. The Labor Code was recently amended to allow women to work without their husbands' written authorization.

40 Art. 215.

41 Art. 454. If he fixes the residence in an abusive manner or contrary to what has been agreed upon, then she can sue him in court. Id. at Art. 455.

42 Code de la Famille Art. 317.

43 See Naomi Cahn and Anne T. Goldstein, Roe and its Global Impact, _ P PenN. J. CON. L. (forthcoming 2004).
} 
five to twenty years. ${ }^{44}$ Associated doctrine, enshrined in the official comments to the penal code, precludes any act other than "coit” (coitus), regardless of its nature or morality, from being treated as rape. ${ }^{45}$ Rather than proceeding through the judicial system, rape cases are sometimes resolved when the perpetrator marries the victim, or pays reparations to her family, ${ }^{46}$ a type of informal resolution that occurs in other countries where women remain second-class citizens. For example, in Peru, until 1997, if one of the perpetrators married his rape victim, then he was exempt from prosecution. ${ }^{47}$ Within some Congolese tribes, there are customs which minimize the impact of rape; for example, in one tribe, when a woman's husband has died, her husband's male relative rape her with impunity, while in another area, a girl can be sequestered and raped for several weeks and, upon her release, the boy who has proved his masculinity need only pay a goat or a small sum of money in compensation. ${ }^{48}$ These legal inequalities, supported by pre-colonial traditions, help provide the context for community and family reactions to the sexual violence. They also establish a climate of impunity, if not tolerance, for gender-based violence.

\section{c. Sexual Violence During the Conflict}

Bohoro Nyagakon is waiting for her third procedure at the Panzi Hospital in Bukavu [a regional Congolese capital].

The story of how she arrived here began on May 12, 2002, when rebel

44 Code Penal Zairois Annote, Title VI, Art. 168, 170 (1995). There is another provision that provides for five to fifteen years of imprisonment for modesty violations committed against a minor under fourteen years old. Id. Sec. 167.

${ }_{45}$ Id. at Art. 170, p. 117.

${ }^{46}$ LaShawn R. Jefferson, In War as in Peace: Sexual Violence and Women's Status 3 (Jan. 2004)(available at http://hrw.org/wr2k4/15.htm; Pratt and Werchick, supra note _, at

${ }^{47}$ See Center for Reproductive Law and Policy, Women of the World: Laws and Policies Affecting Their Reproductive Lives: Peru 176 (avail. at www.crlp.org); see also Jennifer L. Ulrich, Confronting Gender-Based Violence With International Instruments: Is a Solution to the Pandemic Within Reach?, 7 Ind. J. Global Stud. 629, 633 (2000)(similar laws in Fiji and Thailand).

48 Initiative Conjointe de Lutte Contre Les Violences Sexuelles Faites aux femmes et aux enfants en Rdc: Rapport de Mission 15 (2003). 
fighters demanded that she disrobe in her home.

It was 8 p.m. She was eight months' pregnant and had finished a long day of cooking and washing. She was resting in the sitting room of her small hut. "Five of them came at me," she says, looking down.

"I closed my eyes.

"They told my husband to get in another room and they held him down. They were shouting that they would kill him.

"Then, they each had sex with me, five of them. Afterward, I was so bruised and my mind was shutting off."

After the rebels left, Nyagakon's husband carried her through the banana trees under the cover of darkness and on to a boat for the five-hour ride from her town of Niabembe to Kabare, where there was a hospital.

In the middle of the night, doctors had to cut her abdomen open and remove the dead fetus. ${ }^{49}$

The scale and scope of sexual violence ${ }^{50}$ against women in the Congo are almost

incomprehensible. As a spokesperson for the UN World Food Programme observed,

“’We have never come across as many victims of rape in a conflict situation as” in the

Congo. ${ }^{51}$ The sexual violence against women and girls ${ }^{52}$ has affected them physically,

economically, psychologically, and socially. The impact on their communities has been

equally profound, illustrating the vacuum of local authority and the lack of protection

available on an individual, communal, national, and international level. ${ }^{53}$

During the war, tens of thousands, if not more, women and girls were subjected to

various forms of sexual violence. ${ }^{54}$ Women were raped, often by multiple men, and often in front of husbands, children, and other family members. Women were held captive for months or years at a time, subjected to repeated rapes and unable to return to their

\footnotetext{
49 Wax, supra note

50 For an overview of sexual violence issues, see http://www.rhrc.org/pdf/gbv.pdf.

${ }^{51}$ DR Congo Vows to punish rapists from War, Agence France, Jan. 26, 2004 (quoting Christiane Berthiaume)

${ }^{52}$ In this paper, I treat women and girls as constituting a single group. Age should, of course, affect the design of various policies, but such complexities are beyond the scope of this current paper.

53 Local authority prior to the civil war was not democratic, nor particularly responsive; nonetheless, the conflict has allowed the warring factions to enter villages with little resistance, and has also served as a cover for additional lawlessness aside from the militias resulting from the lack of authority.

54 Edith Lederer, U.N. Report: Women Hard-hit by Congo War, available at www.congokin.com/news/categories/society/story1724.shtml
} 
families; penetrated with sticks and guns; and shot in the genital area. ${ }^{55}$ Many women and girls were kidnapped from their communities, and forced to provide sexual services as well as domestic work for the soldiers and militia members. ${ }^{57}$ A woman's age was irrelevant; babies, toddlers, teen-agers, and elderly women have all been subjected to various forms of sexual violence. ${ }^{58}$ Some pygmy women were raped, they explained, because soldiers believed that they would thereby become immune to various illnesses. ${ }^{59}$

The actual number of women subjected to gender-based violence is not known because attacks often occur in remote areas, where it is difficult to contact victims. Observers believe that, once it is finally established, the number of women subjected to sexual violence in the Congo will be much higher than the numbers in either Rwanda (approximately 50,000) or Bosnia (about 20,000) ${ }^{60}$ Moreover, women are generally frightened to report their rapes, fearing ostracism from their homes and communities and reprisal for daring to speak; there is also a lack of awareness of the possibilities for help. Even if women do find the proper authorities, they may be unable to file a complaint because they lack the money or because the authorities are in collusion with the military. Not only were civilians the victims of gender-based violence, so too were girl and female soldiers. Joining a militia did not provide immunity from violence. In its report

55 See The War Within the War, supra note _ ; JSI Research and Training Institute, Assessment of Reproductive Health in the Democratic Republic of Congo 9 (July 2002), available at http://www.rhrc.org/resources/general_reports/index.html.

57 See Human Rights Watch, Policy Paralysis: A Call for Action on HIV/AIDS-Related Human Rights Abuses Against Women and Girls in Africa, p. 3 (Dec. 2003)(available at http://www.hrw.org/reports/2003/africa1203/7.htm).

58 See Jan Goodwin, Silence=Rape, THE NATION, March 8, 2004

${ }^{59}$ Coalition Contre Les Violences Sexueulles en Republique Democratique cdu Congo, Rapport Sur Les Violations des Droits Humains au Sud Kivu: Les Viols et Violences Sexuelles: Casser L'Impunite du Viol en R.D.C. 7 (Dec. 2003)(report on file with author); Heritiers de la Justice, Rapport, supra note —, at 4.

60 See Goodwin, supra note _; IRIN, DRC: Focus on Rampant Rape, Despite Ned of War , March 2004 (available at http://www.aegis.com/news/irin/2004/IR040313.html) 
on child soldiers in the Congo, Amnesty International found that virtually all girl soldiers had either been raped or otherwise sexually attacked by commanding officers or others in their units. ${ }^{61}$ Few places in the conflict region are safe; women and girls are raped in camps for the internally displaced ${ }^{62}$ and MONUC troops have also been accused of sexual violations. ${ }^{63}$ And, female refugees have agreed to exchange sex for food with the peacekeeping troops. ${ }^{64}$

Each of the warring factions has also been implicated in the commission of sexual violence. It is difficult to define the "good guys" or the "bad guys" given the complexity of the conflict and the number of groups and other African countries involved. Rape is used by all sides both as a weapon of war, to terrorize and dehumanize the population, and as an extension of the widespread pillaging that occurred. ${ }^{65}$ As in other African wars, it is typically unarmed civilians who are most likely to be victimized. ${ }^{66}$ The rapes are used to establish the power of the winning soldiers to take what they want, to punish anyone suspected of sympathizing with another faction, and to humiliate individuals and their communities. ${ }^{67}$ Because rape is defined under Congolese law as a violation of a

\footnotetext{
${ }^{61}$ Amnesty International, Democratic Republic of Congo: Children at War 4 (2003)(available at http://www.amnestyusa.org/countries/dr_congo/reports.do.

${ }^{62}$ Goodwin, supra note .

63 Conversations with non-governmental organization and author, spring 2004; see also Vann, supra note _ , at 15 (discussing Save the Children and UNHCR on gender-based violence committed by aid workers and peacekeeping forces.)

${ }^{64}$ Kate Holt, DR Congo's Shameful Sex Secret, BBC News, June 3, 2004.

65 IRC proposal, p. 3; see Heritiers de la Justice, Rapport Sur La Situation de Viols et Violences Sexuelles au Sud-Kivu 4 (Nov. 2003)(available at www.heritiers.org).

66 "War in this context is virtually unrecognizable ....Parties to conflicts do not fight to win; direct armed clashes are avoided, minimized, or simulated; strategic towns are not taken; and armed violence is mainly directed at unarmed civilians, who constitute the vast majority of casualties. Looting of civilians is the primary form of payment for both soldiers and rebels.” Menkhaus, supra note _, (manuscript at 7). In a survey of displaced households in Sierra Leone, $94 \%$ reported that members had experienced some form of gender-based violence. UNHCR Guidelines, supra note _, at 7.

67 Pratt and Werchick, supra note _, at 8. For the now classic view of rape as a means of domination rather than sexual desire, see Susan Brownmiller, Against Our Will: Men, Women, and Rape (1975).
} 
man's honor, it is seen as a humiliation to men too. ${ }^{68}$ As Kelly Askin notes, genderbased violence demoralizes the raped individual and her community, and it also “entertain[s] or reward[s]” soldiers, encouraging them t o continue the conflict. ${ }^{69}$ The scale of sexual violence differs from pre-war rape cases, which typically involved individuals, not armed groups. ${ }^{70}$ Gender violence has additional indirect effects on other women, making them fear for their own and their children's safety as they conduct their daily activites, ${ }^{71}$ and helping to foster, post-conflict, a situation with ongoing sexual violence, including rape. ${ }^{72}$ Gender-based violence has far-reaching effects, including health, psychological, security, and legal. ${ }^{73}$

1. Health impact: The health impact of gender-based violence is, perhaps, the easiest to comprehend. The consequences for women's health range from unwanted pregnancies, miscarriages caused by the abuse, illness or death from illegal abortion, damaged vaginas resulting from rape or knives or gunshots, and sexually transmitted diseases, including HIV-AIDs. Although injured vaginas typically result from early childbirth, this is not true in the Congo, where doctors have seen so many injured vaginas

\footnotetext{
68 See ReBecca Cook, Gender, Health, and Human Rights, in Health and Human Rights: A Reader 253, 260 (Jonathan Mann et al. eds. 1999)(discussing various harms caused by sexual violence during armed conflicts).

${ }^{69}$ Askin, The Quest, supra note _, at 513. Sherrie L. Russell-Brown explores why commanders allow their soldiers to commit sexual violence, including that prevention is not a high priority, that sexual violence may simply be viewed as another war tactic that dehumanizes the population, and a lack of sense of accountability for such crimes. Sherrie L. Russell-Brown, The Last Line of Defense: The Doctrine of Command Responsibility, Gender Crimes in Armed Conflict, and the Kahan Report (Sabra and Shatilla) at 9 (forthcoming 2004)(on file with author).

${ }_{70}$ Pratt and Werchick, supra note _, at 9.

71 See Christine Chinkin, Rape and Sexual Abuse of Women in International Law, 5 EUR. J. INTL. L. _, 6 (1994)(available at http://ejil.org/journal/Vol5/No3/art2.pdf)

72 See Ward, supra note _, at 13. Ward points out that the focus on sexual violence during conflict overlooks other forms of violence against women that occur before, during, and after the conflict, including domestic violence. $I d$.

${ }^{73}$ For a useful chart summarizing these effects, see UNHCR, Guidelines for Prevention and Response: Sexual and Gender-Based Violence Against Refugees, Returnees, and Internally Displaced People 54 (2003) (available at http://www.rhrc.org/pdf/gl_sgbv03_04.pdf).
} 
that they record them as a "crime of combat." ${ }^{, 4}$ The chief medical office at one provincial hospital estimated that $80 \%$ of the women treated there had sexually transmitted diseases. ${ }^{75}$ Because abortion is illegal, women may try to arrange illegal abortions, or carry the baby to term in a country where the maternal mortality rate is estimated to be the highest in the world, at 1835 women per 100,000 births. ${ }^{76}$ I have been told of one case where a woman who had been raped was sentenced to twenty years in prison for aborting her fetus. ${ }^{77}$ Emergency contraception is rarely available or accessible.

HIV-AIDS is also being spread by the conflict. "Between $40 \%$ and $60 \%$ of the foreign soldiers who fought in Congo's war were HIV-positive. After five years of Rwandans, Ugandans, Zimbabweans and Angolans marching through Congolese villages, scientists have observed a frenetic mix of different HIV sub-types in local bloodstreams, which could cause new drug-resistant strains to develop.” ${ }^{78}$ The HIVAIDS rate throughout all of the Congo is approximately 6-7\%, but estimates of its prevalence in the conflict zones are much higher. In the North Kivu region, one of the cities experiencing conflict, the World Health Organization estimates that $54 \%$ of adult women and $26 \%$ of children have been infected. ${ }^{79}$ Although the militias are primarily responsible for the high infection rate, the peace-keeping forces are also culpable. ${ }^{80}$

\footnotetext{
74 Wax, supra note _.

75 Assessment, supra note _, at 9; see also AIDS Becoming Becoming Africa's Top Human Security Issue, http://www.unaids.org/whatsnew/press/eng/pressarc00/ny10100.html.

${ }^{76}$ See Cahn and Goldstein, supra note _. . By contrast, the maternal mortality rate in the US is 12 . Id. 77 Conversation with ML, May 25, 2004, Kinshasa (need permission).

${ }^{78}$ Love and Death, THE ECONOMIST, Jan. 17, 2004.

79 Elisabeth Rehn and Ellen Johnson Sirleaf, Women, War and Peace: The Independent Experts' Assessment of Armed Conflict on women and Women's Role in Peace-Building 48 (2002)(available at http://www.unifem.undp.org/resources/assessment) (citing UNICEF and WHO $<$ Health Sector Assessment in Eastern Congo, available at http://www.who.int/eha/disasters).

${ }^{80}$ Rehn and Sirleaf, supra note _ , at 55. Peacekeepers are associated, in conflict zones, with increased prostitution and sexual exploitation, not necessarily the rapes committed by the militia. Id. at 61 .
} 
The violence also has psychological consequences for the women. Women experience insomnia, depression, and other symptoms, and may become suicidal, experiencing post-traumatic stress syndrome. ${ }^{81}$ Women most often continue to live in the environment in which they were abused, and are often terrified to perform their necessary daily tasks, such as working in the fields or gathering wood in the forests for cooking, because that is where the violence occurred. They may also feel so stigmatized that they are unable to leave their homes.

All of these symptoms are exacerbated by the unavailability of appropriate health services. Until recently, less than $1 \%$ of the government spending is for health programs. ${ }^{82}$ The government's Ministry of Health admits that less than $30 \%$ of the country's health zones are "functional." ${ }^{\text {"83 }}$ And years of war have left many health centers essentially inoperative, with no medical supplies, and no money available for salaries for health workers. ${ }^{84}$ Women may not know how important it is for them to find medical care; and, even where it is available, medical care is often too expensive.

2. Social: More than three-quarters of rural families in the Eastern Congo have been displaced at least once during the conflict. ${ }^{85}$ Many women are unable to return to their families. In some cases, their husbands, mothers, fathers, and other family members have been killed, so there is no one to return to. In other cases, their husbands and fathers have rejected them, sometimes claiming that the women have sexual diseases, sometimes

\footnotetext{
81 See In War as in Peace, supra note _, at 9.

${ }^{82}$ JSI Research and Training Institute for the Reproductive Health for Refugees Consortium, Assessment of Reproductive Health in the Democratic Republic of Congo 3 (July 2002).

83 Id. At 4.

84 Rehn and Sirleaf, supra note _, at 128.

85 War Within the War, supra note _, at 18 (estimating that 80\% have fled their homes).
} 
explaining that the man's honor has been damaged, generally blaming the woman herself rather than the militias. One woman explained what happened when she returned home: "I tried to hide it from my husband but he found out. He said that I had accepted it voluntarily. He said this although I had bruises and marks where the soldiers had pressed their fingernails into my inner thigh." ${ }^{86}$ Men may have taken another wife, and relegated the first, raped wife to secondary status. ${ }^{87}$ Many young men told one local human rights group that they would not marry a woman who had been subjected to sexual violence. ${ }^{88}$ Young unmarried women who have been raped and had children may be scorned by their families, fleeing their villages. ${ }^{89}$ By contrast, many of the men who became soldiers have been accepted into their former communities.

The women who have been rejected by their families and communities are further victimized because they have no economic support. ${ }^{90}$ Their families will not provide food, and they often fear leaving their houses to work in the fields or to sell goods at the local market. If their rape has resulted in a pregnancy, then their child is also ostracized. The mothers themselves may reject children resulting from rape because the children are

\footnotetext{
${ }^{86}$ War Within a War, supra note _ , at 64 . Victim rejection and blaming is a common attitude towards women raped during conflict. See In War as In Peace, supra note _, at 8.

${ }^{87}$ Assessment, supra note _, at 10, 14. Polygyny is not uncommon in the Congo, but sexual violence provides another reason for a man to take additional wives.

${ }^{88}$ Heritiers, supra note _, at 7.

89 One girl explains: "I came to this camp nearly six months ago when the fighting got bad in our village," Faela explains. "Every night the [Congolese militia] soldiers would come to our hut and make my sisters and I do it with them. We had no choice. If we said 'No' then they would hurt us. "Sometimes they put their guns against my chest and sometimes between my legs. I was really scared." . . . Scared indeed, scared enough to leave the village where she had been born and begin the long walk through the jungle to the IDP camp, knowing she was pregnant by one of the fighters who raped her. "I had Joseph in the forest," Faela says. "My father cannot help me any more - he is ashamed of me because I had this baby when I am not married." Holt, supra note_.

90 War Within a War, supra note -_, at 65-66.
} 
a visible and constant reminder of their humiliation. ${ }^{91}$ In neighboring Rwanda, raped women sometimes labeled their children "little killers."92

\section{Responses to Sexual Violence}

Justice and reconciliation are often framed as opposite ends of a continuum. ${ }^{93}$

Either criminals are treated as such, and prosecuted; or the community focuses on overcoming a violent past and reintegrating potentially indictable war criminals into their home communities, granting a fairly open-ended amnesty. ${ }^{94}$ Because of the relatively recent advent of international justice and culpability for crimes committed during conflicts, ${ }^{95}$ this dichotomy makes sense. The availability of international and national tribunals to impose criminal liability for war crimes helps show the horrendous nature of these crimes. Prosecution and consequent accountability indicates the level of gravity with which the community of nations has begun to approach these immoral acts.

The addition of gender-based violence is even more recent; taking these crimes seriously requires indictments, trials, and judgements so that the defendants understand how they have wronged their victims and society. ${ }^{96}$ The new International Criminal Court statute, which has specific provisions dealing with gender-based violence including

91 Pratt and Werchick, at 12.

92 Emily Wax, Rwandans are Struggling to Love Children of Hate, WASH. Post, Mar. 28, 2004 at A1.

93 See Jose Alvarez, Crimes of State/Crimes of Hate: Lessons From Rwanda, 24 YALE J. INTL. L. 365,403 (1999) (International lawyers contend that amnesties "signal lawlessness to victims, to perpetrators, and to relevant national communities, as well as to international society as a whole. This message is ostensibly countered and the rule of law affirmed through international criminal accountability”).

94 See Erin Daly, Transformative Justice: Charting a Path to Reconciliation, 12 INTL. LEGAL PERSPECTIVES 73, tan.7 (2001/2002)

95 See _ (history of war crimes); For a compelling history of the crime of genocide, see SAMANTHA Power, “A Problem From HelL”: AmERICA AND THE AgE OF GENOCIDE (2002). She argues that the United States has, for a variety of reasons, including a lack of will to do so, done little to prevent or respond to genocide.

96 See, e.g., Kelly D. Askin, Sexual Violence in Decisions and Indictments of the Yugoslav and Rwandan Tribunals: Current Status, 93 A.J.I.L. 97, 99 (1999). A parallel move to criminalization has occurred in the domestic violence context. See, e.g., Minow, Between Vengeance and Forgiveness, supra note _, at 977-978; Cheryl Hanna, __ HARV. L. REV. 
a victim-witness unit, is an example of the development of a new approach to sexual violence. ${ }^{97}$ Kelly Askin, an extremely thoughtful scholar of rape as a war crime, observes that there is a "tendency to ignore gender and sex based crimes. The crimes are intensely personal, the injuries often less visible, and the details provoke discomfort and aversion. But the alternative is silence, impunity, and grave injustice."98

There have been repeated calls to use the formal justice system to end the impunity that has protected rapists in the Congo. Human Rights Watch recently argued for "the creation and financial support of measures to enable adequate investigation and prosecution of a large number of these crimes."99 also recommended the development of a fair and transparent Truth and Reconciliation Commission ${ }^{100}$ to handle some of the crimes committed during the war. Overall, these recommendations contemplate a justice and parliamentary system that would be sensitive to the needs of victims, while ending the impunity that has protected perpetrators. ${ }^{101}$ Others have suggested a regional tribunal, that would draw judges from the Congo and

\footnotetext{
97 E.g., Jocelyn Campanaro, Note, Women, War, and International Law: The Historical Treatment of Gender-Based War Crimes, 89 GEO. L.J. 2557 (2001); Barbara Bedont \& Katherine Hall Martinez, Ending Impunity for Gender Crimes Under the International Criminal Court, BROWN JOURNAL OF WORLD AFFAIRS (1999)( detailed account of the statute's provisions on crimes of sexual Rana Rahn-Lehnhardt, Note: One Small Step for Women: Female-Friendly Provisions in the Rome Statute of the International Criminal Court Court, 16 BYU J. PuB. L. 317, 345-46 (2002): "Rape still cannot be prosecuted as a crime in and of itself - as rape. Instead, it must be prosecuted as a subset of a war crime, a crime against humanity or genocide. Additional reasons why this step forward can arguably be classified as only a small step are because perpetrators of violence against women continue to serve relatively short sentences, because the ICC did not provide for means by which to deter future aggressors, and because protection for witnesses and victims is not yet adequate."

${ }^{98}$ Kelly D. Askin, Prosecuting Wartime Rape and Other Gender-Related Crimes under International Law: Extraordinary Advances, Enduring Obstacles, 21 BERKELEY J. INTL. L. 288, 346 (2003).

${ }^{99}$ Human Rights Watch, Democratic Republic of the Congo: Confronting Impunity (Jan. 2004) at V.b. (available at).

${ }^{100}$ See infra for a discussion of Truth and Reconciliation Commissions.

101 See infra for HRW's candid acknowledgement of the difficulties of improving the Congo's existing justice system.
} 
from other countries as well. ${ }^{102}$ Such "hybrid tribunals" combine local participation with the legitimacy of international jurists and support. ${ }^{103}$

On the other hand, as argued by opponents of the death penalty, the legal system may compound the violence experienced by the victim by forcing the victim to undergo further trauma as she testifies about the violence and confronts the perpetrator. Speaking at a trial and reliving the experience, particularly in a legal setting without special protections for witnesses, may be extremely difficult and unwise. And, given that many perpetrators live in the same communities as their victims, legal proceedings that humiliate them will not help with resettlement and security. ${ }^{104}$ Trials are often justified as promoting individual accountability and creating opportunities for public discussion. ${ }^{105}$ But that implies adequate publicity, and a sufficiently large number of defendants so that the tribunal's deliberations are neither cabined nor overwhelmed, ${ }^{106}$ as well as a society willing to undertake reflection.

Moreover, unless tribunals outside of the country control the investigation and prosecution, victims, witnesses, and the concept of justice itself depend on countryinternal mechanisms. As happened in some of the early trials of Rwandan genocidaires, there were serious questions of fairness and adequate process because of deficiencies in the internal justice system, such as inadequate - or no - legal representation for

102 See generally William Burke-White, Regionalization of International Criminal Law Enforcement: A Preliminary Exploration, 38 Tex. Int'l L.J. 729 (2004)(assessing the utility of regional tribunals); Woodrow Wilson School briefing report (need permission).

103 See Askin, Quest for Post-Conflict Gender Justice, supra note _, at 521.

104 See Minow, Between Vengeance and Forgiveness, supra note _, at 121. She points out that, "if the longer term goals include avoiding cycles of revenge, social reintegration of at least lower-level perpetators should be pursued. In many circumstances, demonizing all on 'that side' means demonizing large segments of the society.” Id.

105 Jose Alvarez; see Drumbl, Punishment, Postgenocide, supra note _, at 1279-1280.

106 Drumbl, at 1280. 
defendants. ${ }^{107}$ In the Congo, because of the widely-acknowledged disarray of the justice system, there would be similar problems.

This section discusses three possible responses to gender-based sexual violence, reviewing the recent development and growing recognition of rape as a war crime and then exploring the concept of restorative justice, which represent a move away from the more traditional criminal justice system. Finally, the section suggests principles for developing an approach to sexual violence that combines both traditional and newer methods.

\section{a. Sexual Violence as a violation of international law}

Accountability for state-sponsored abuses against individuals during war has a longer history than does accountability for individuals who commit crimes during war, with 1947 marking the date for "the most significant effort to create a comprehensive regime for individual criminality." ${ }^{108}$ States can be held liable for sexual violence under the laws of war or pursuant to international human rights law, including genocide and torture, and individuals can be held liable for crimes of war and crimes against humanity. ${ }^{109}$

International humanitarian law, which applies once an armed conflict has begun, has traditionally accorded minimal attention to sexual violence. ${ }^{110}$ The Geneva Conventions of 1949 prohibit violence against civilians, including “outrages upon personal dignity.”111 Until the past decade, sexual violence has been treated as a crime of honor. ${ }^{112}$ For

107 See POWER; see Minow, supra note _, at 124.

108 STEVEN R. RATNER AND JASON S. ABRAMS, ACCOUNTABILITY FOR HUMAN RightS ATROCITIES IN INTERNATIONAL LAW: BEYOND THE NUREMBERG LEGACY 7 (1997).

109 Chinkin, supra note _, at 6; find Askin/Alyson, please find more contemporary cite and clarify.

110 See Askin, Prosecuting Wartime Rape, supra note __, at 295-96.

111 Art. 3, 1949 Geneva Conventions. Full Cite needed. Geneva Convention relative to the Protection of Civilian Persons in Time of War art. 3 (Aug. 12, 1949), http://www.unhchr.ch/html/menu3/b/92.htm

112 See Shattered Lives, supra note -_, at n. 41 (" Article 27 of the Fourth Geneva Convention prohibits "any attack of [women's] honor, in particular against rape, enforced prostitution, or any form of indecent 
example, the Fourth Geneva Convention Relative to the Protection of Civilian Persons in

Time of War specifically protects women against rape as an "attack on their honor.”113

International criminal law and international human rights law also provide protection against sexual violence. ${ }^{114}$ The Convention on the Elimination of All Forms of

Discrimination Against Women and the International Covenant on Civil and Political

Rights, among other instruments, ${ }^{115}$ guarantee the equal rights of men and women. The

UN’s 1993 Declaration on the Elimination of Violence Against Women defines gender-

based violence broadly, to include any gender-based act that causes physical, sexual or

psychological harm. And in 2000, the UN adopted a resolution that "calls upon all

parties to armed conflicts to take special measures to protect women and girls from

gender-based violence."116

Sexual violence against women has, during the past decade, begun to be recognized

as a war crime, a crime against humanity, an instrument of genocide, and a means of

assault." The Geneva Convention Relative to the Protection of Civilian Persons in Time of War, Aug. 12, 1949, 6 U.S.T. 3516, 75 U.N.T.S. 287, Article 27. Protocol II to the Geneva Conventions forbids rape explicitly, but characterizes it as an outrage on personal dignity rather than as a physical assault. Protocol Additional to the Geneva Conventions of 12 August 1949, and Relating to the Protection of Victims of Non-International Armed Conflicts, opened for signature December 12, 1977, Article 2(e), 1125 UNTS 3, 16 ILM 1442 (1977) [Protocol II].”)

${ }^{113}$ Geneva Convention relative to the Protection of Civilian Persons in Time of War, art. 27 (Aug. 12, 1949), http://www.unhchr.ch/html/menu3/b/92.htm; War Within the War, at 86.

114 "International humanitarian law is only invoked once an armed conflict exists, whereas crimes against humanity and genocide do not need a connection to war in order to be prosecuted ... International human rights and international humanitarian law prohibit torture and slavery, yet redress efforts depend up on which body of law is applied ... . within the context of war, international human right slaw can still provide protections.” Askin, Prosecuting Wartime Rape, supra note _, at 291.

${ }^{115}$ Declaration on the Elimination of Violence Against Women, G.A. Res. 48/104, U.N. GAOR, $48^{\text {th }}$ Sess., Supp. No. 49, at 217, U.N. Eoc. A/RES/48/104 (1993), Art. 1.

${ }^{116}$ Jeanne Ward, If Not Now, When? Addressing Gender-Based Violence in Refugee, Internally-displaced, and Post-Conflict Settings 10 (available at http://www.rhrc.org/pdf/gbvintro.pdf); see generally, Maya

Steinitz, The Role of International Law in the Struggle Against Sex-Based and Gender-Based Violence Against Refugee Women (2001)( available at http://www.rhrc.org/pdf/steinitz.pdf). Alison - please get the cite for the resolution itself. 
persecution. ${ }^{117}$ War crimes now include rape, sexual slavery, forced prostitution, enforced pregnancy, and other comparable crimes. ${ }^{118}$ The first judgment issued by an international tribunal that recognized rape as a war crime occurred in the case against Jean-Paul Akayesu, a former mayor in Rwanda, who was convicted of failing to stop rape and murder by his subordinates, ${ }^{119}$ and the international tribunals have issued several other judgments recognizing sexual violence as a violation of international law. ${ }^{120}$ The Rome Statue of the International Criminal Court defines rape and other serious forms of sexual slavery as "crimes against humanity" when it is committed as part of a broad attack against civilians, ${ }^{121}$ and as "war crimes," when committed as part of a plan or when there are massive numbers of these crimes. ${ }^{122}$

In a forceful critique, Hilary Charlesworth argues that, pursuant to international humanitarian law, rape should be prosecuted not as a community or group-based offense, but as a crime against women. ${ }^{123}$ She notes that the Akayesu judgment defined rape as an

117 Kelly D. Askin, The Quest for Post-Conflict Gender Justice, 41 Colum. J. TransnaT’L. L. 509, 520 n.43 (2003); see generally Askin, supra note_; Christine Chinkin, Rape and Abuse of Women in International Law, 5 EUR. J. INT'L. L. 362 (1994); Theodor Meron, Rape as a Crime under International Humanitarian Law, 87 AM. J. INT’L. L. 424 (1993). When it comes to genocide, there are complicated issues concerning its legal status as international law, and its scope. Ratner and Abrams observe that there have been questions about "whether rape committed in the Balkan War was genocidal, especially in light of the hope expressed by some Serb attackers that they would make their victims give birth to Serb babies ... Where an attacker rapes a victim solely as an act of vengeance or hostility toward the victim, the rape is not genocidal, even if the attacker has selected the victim on the basis of her religion or ethnicity ... if evidence suggests that the attacker committed the rape as part of an effort to drive members of the victim's group into conditions which the attacker hopes will lead to their deaths, a finding of genocide becomes more plausible.” Ratner and Abrams, supra note -_, at 42.

It is also a form of torture. See Cook, supra note _, at 260.

118 See Amnesty International, It's In Our Hands: .Stop Violence Against Women 77 (2004). The changing norms of international law result, in part, from strong advocacy by women's groups. See Askin, Prosecuting Wartime Rape, supra note _, at 347.

119 Prosecutor v. Akeyesu, Judgement, ICTR-96-4-T, 2 Sept. 1998. Please fill in cite and other details re rape from ICTR website, and also ICTY rape conviction.

${ }^{120}$ For a thorough review of these judgments, see Askin, Prosecuting Wartime Rape, supra note _, at 318-346.

121 Rome Statue of the ICC, Art. 7, 1.g.

122 Art. 8, Sec. (e)(vi)

${ }^{123}$ Charlesworth, supra note _ at 394. 
act of genocide only when it can be connected with the intention of assaulting a

community, thereby defining rape as a private, individual violation unless it can be tied to the public harm of destroying a community. ${ }^{124}$ Such a definition, while an expansion of international law, still relies on traditional notions of women's roles and bodies. Instead, rape could be redefined "as a crime of violence against women."125 On the other hand, the Akayesu judgment is "monumental" in its recognition that rape can, indeed, constitute genocide and a crime against humanity. ${ }^{126}$ Trials can be dramatic illustrations that there is no impunity for sexual violence. ${ }^{127}$

b. Additional means of justice

In the United States, advocates have succeeded in strengthening rape laws, by, for example, abolishing the exceptions for marital rape and increasing the sentences for rapists. ${ }^{128}$ Yet these reforms have had limited impact on the rates of rape reporting, prosecution, or conviction. ${ }^{129}$ Instead, as advocates recognize that it is community attitudes that aid in tolerating sexual violence even with the existence of strengthened laws, they have suggested that interventions should focus "both at the level of holding perpetrators more accountable and at the level of reducing public acceptance.”130 Prosecutions alone, then, have not resulted in the desirable outcome of decreasing rape.

124 Charlesworth, supra note _, at 387.

125 Charlesworth, supra note — international criminal law, the distinction between crimes committed by state and nonstate actors. Id. at 387-88.

126 Askin, Prosecuting Wartime Rape, supra note _, at 318.

127 See Drumbl, Punishment, supra note _, at 1277-78 ("trials may have significant declaratory values. Trials may set standards, codify legal principles and create precedent . . . a trial may be needed to debunk the arrogance of dismissive leaders”); see generally, Jose E. Alvarez, Rush to Closure: Lessons of the Tidioute Judgment, 96 Mich. L. REV. 2031 (1998). .

${ }^{128}$ MARY P. Kiss, et al., Restorative Justice fOR SEXUAL ViolenCe: RePAiring Victims, BuiLding COMMUNITY, AND HOLDING OFFEndERs ACCOUNTABLE, at 4.

129 Id. Similar efforts in the domestic violence context have had relatively little impact on lowering its prevalence. See Hopkins, Applying Restorative Justice, supra note __, at 2.

${ }_{130}$ Id. at 5. See Owen Jones, Evolutionary Analysis and Rape, _ CAL. L. REV. 
In the international arena, international tribunals do not necessarily deter future crimes, but serve instead to hold perpetrators accountable and as vivid reminders of the conflict's destruction. ${ }^{131}$ As Christine Chinkin pointed out more than a decade ago, the focus of international tribunals "is on punishing the wrongdoers, not on providing compensation and support to those who have suffered." ${ }^{\text {132 }}$ Advocates have begun to develop restorative justice approaches which seek to repair harm, support a victimcentered legal process, and change the community's attitudes. ${ }^{133}$ Similarly, prosecuting all war criminals, while an enormously significant and critical endeavor, may not always serve the interests of justice, of the community, nor of the world community. ${ }^{134}$ International law scholars have begun to discuss a "third course," that is neither prosecution nor amnesty, ${ }^{135}$ and to suggest that justice solutions for each transitional society will be context-specific. ${ }^{136}$ This section explores restorative justice as well as “social services justice,” which I define as a concept that allows justice to move beyond reparations and retribution and punishment that focuses on both immediate and long-term solutions for victim, potential victim, and community.

a. restorative justice: Some of the newer approaches, based on principles of restorative justice, emphasize the importance of transforming the culture, not just holding perpetrators liable, or excusing them so that they can resume their pre-conflict lives; of

\footnotetext{
131 Martha MinNow, Memory and Hate: Are there Lessons from Around the World?, in BREAKING THE CyCles of HATRED: MEMory, LAW, AND RePAir 14, 22 (Nancy Rosenblum and Martha Minnow eds. 2002)("the tribunals and their work offer rituals of accountability, defying impunity and public acknowledgment, defying forced forgetting”); see Nancy L. Rosenblum Justice and the Experience of Injustice, in id., at 77, 79("formal justice, cool and cognitive" does not "quench[] the survivor's desire for revenge").

${ }^{132}$ Chinkin, supra note _, at 12.

133 Hopkins, Applying Restorative Justice, supra note _, at 6.

${ }^{134}$ See Mark Drumbl, Toward a Criminology of International Crime, 19 OHIO ST. J. DIPS. RES. 263, 274 (2002); Drumbl, Punishment, supra note _, at 1230-1232..

135 See Daly, supra note _.
} 
reconciliation and prevention and repairing harmed lives, not retribution. ${ }^{137}$ Examples of the "third course" include truth and reconciliation commissions, reparations programs, or lustrations. ${ }^{138}$ Restorative justice can take many other forms as well, including civil proceedings, mediation, and community conferencing, although these are not all appropriate for sexual violence. ${ }^{139}$ While restorative justice focuses on the individual, the perpetrator, and the community, it also acknowledges that the crime is a wrong against the state as well. Truth and reconciliation commissions, for example, generally take testimony from witnesses and then compile reports, providing the opportunity to gather information from many people and then synthesize it. ${ }^{140}$ They do not conduct trials, and witnesses are typically not subjected to litigation techniques, such as cross-examination; witnesses are able to tell their stories outside of the formal legal framework. Because they collect multiple and full stories, TRCs can provide extensive factual records that document the violence. ${ }^{141}$

Restorative justice is concerned not just with violations of the law but also with violations of relationships ${ }^{142}$; it brings victims and offenders together so that the victim receives reparations, the offender takes responsibility, and the community becomes involved in the healing process. Its many different forms, including victim-offender

136 See Daly, supra note _ ; Mark Drumbl, Punishment, PostGenocide: From Guilt to Shame to Civis in Rwanda, 75 NYU L. REV. 1221, 1225-26 (2000).

137 See Daly, supra note _ ; Koss, Restorative Justice, supra note _ , at 5.

138 Drumbl; Daly; etc.

139 Hopkins, Applying Restorative Justice, supra note _, at 7.

140 See Minow, supra note _, at 128-29; Mark Vassals, Comment, Truth and Reconciliation Commissions: General Considerations and a Critical Comparison of the Commissions of Chile and El Salvador, 33 U. MiAmi InTER-AM. L. REV. 153 (2002) (citing Priscilla B. Hayner, Fifteen Truth Commissions - 1974 to 1994: A Comparative Study, 16 HuM. RTS. Q. 600 (1994); Angelica Schlock, Truth and Reconciliation Commissions, ILSA J. INT’L \& COMP. L. 415 (1998)).

141 See Rosenblum, supra note _, at 94.

142 See Umbrae, supra note _, at 1 . As Umbrae and his co-authors note, however, restorative justice is a broad concept. Id. at 19. For example, direct conferencing of all involved is often assumed to be a critical 
mediation, which typically brings together the victim, offender, and a community mediator; family conferencing, which involves the families of both the victim and perpetrator; and healing circles, which involve the community as well as the victim and offender, have been adapted to a variety of crimes, including child abuse and neglect as well as sexual violence against women. ${ }^{143}$ The perpetrator must admit guilt before becoming involved in restorative justice, ${ }^{144}$ so this alternative does not imply impunity, and is not an alternative that precludes prosecution or other legal options. But it can result in providing victims with structure, support, and choices, while strengthening the community’s understanding of the victim's situation, and increasing community deterrence of future attacks. ${ }^{145}$ Restorative justice can include reparations such as apologies, financial remuneration, personal service, and community service. ${ }^{146}$

component of restorative justice, yet even that fundamental concept is being reframed to suggest that there should be attempt to include all stakeholders. Id.

143 Id. at.1; see Donna Coker, Enhancing Autonomy for Battered Women: Lessons from Navajo PeaceMaking, 47 UCLA L. REV. 1 (1999).

${ }^{144}$ See Kiss, Blame, Shame, and Community, supra note _ , at 8; Coker, supra note _.

145 Kiss, supra note _, at 9 . Koss suggests that a series of anticipated benefits result from restorative justice:

offering victims choice about how their violation is addressed and empowering them in the context of a nonadverserial process; . .

multiplying the community's social control resources by providing a process to respond to the violation; maximizing reintegration by maintaining the perpetrator in the community and offering a way to make amends a concrete duty-paid end point at which they are no longer stigmatized; improving recovery outcomes and reducing revictimization by providing social validation and increasing access to services;

accomplishing targeted prevention by aiming antiviolence communications to family and peer group of known perpetrators; and by contributing to general deterrence ... . undercutting societal supports for gender-linked abuse, and increasing victim willingness to report crimes.

Id.

${ }^{146}$ Mark S. Umbriet et al., Center for Restorative Justice \& Peacemaking, The Impact of Restorative Justice Conferencing: A review of 63 Empirical Studies in 5 Countries 9 (2002), available at http://ssw.che.umn.edu/rip/Resources/RJP\%20CONFERENCING-mono\%205-5-02.pdf. Reparations suggests the "paradoxical search to repair the irreparables." MinOw, Memory and Hate, supra note _, at 23. As she notes, money cannot compensate for the nonmonetary harms, although it can help restore the victim's dignity and, perhaps, where money actually can be exchanged, livelihood. 
For sexual violence in the Congo, a restorative justice approach provides a useful, albeit unrealistic, perspective on how to heal the women and their communities. Where the perpetrator's identity is known, and if any assets are available, then the perpetrator can make reparations. Otherwise, he can acknowledge his wrongdoing and provide non-monetary services to the victim. In the many cases where the perpetrators' identity is not known, the community can make reparations to the victim.

Nonetheless, the success of any restorative justice approach depends on the commitment of the individuals involved, but also requires community monitoring and enforcement of any outcome. ${ }^{147}$ Moreover, the community must be supportive of the process and outcome and willing to recognize the harms experienced by the victim. ${ }^{148}$ Restorative justice requires resources focused on creating the environment for discussion between the parties, facilitating the discussions, and then monitoring performance. For example, pursuant to a $\$ 1.5$ million grant, the RESTORE (Responsibility and Equity for Sexual Transgressions Offering a Restorative Experience) program in Arizona, which focuses on date and acquaintance rape and nonpenetration offenses, first undertakes an extensive evaluation of the appropriateness of a case, including screening, an intake assessment, which involves "a safety assessment; to decide who will be attending the conference with the victim; to prepare her to describe the injury she has experienced, and to formulate appropriate reparation expectations." ${ }^{149}$ There may be an additional preparatory meeting with the victim and members of her support community before a

\footnotetext{
147 See Koss, Blaming, Shaming, supra note _, at 8.

${ }^{148}$ See Hopkins, Restorative Justice, supra note _ at 9 n.34 (recounting criticism of restorative justice based on the relevant community's failure to understand).

149 Koss, et al, Repairing Victims, supra note _, at 7. The following discussion of the program draws on the description in Koss, et al., and C. Quince Hopkins, Mary P. Koss, and Karen J. Bachar, Incorporating Feminist Theory and Insights into a Restorative Justice Response to Sex Offenses, in Violence Against Women (forthcoming).
} 
conference is held with two facilitators, who are generally social service professionals.

The perpetrator undergoes a similar intake assessment, and must also sign a

confidentiality agreement; his inducement to participate is that successful program

participation means that he will not be referred for prosecution and will have no

conviction record. At the conference, he must describe what he has done, and then the victim describes how he has affected her, before participants develop a redress plan. The conference facilitators provide follow-up for one year, with weekly phone calls and monthly meetings. There is also a community board which receives the reports written by the conference facilitators. The RESTORE program obviously relies not just on the commitment of the victim and perpetrator, but involves social service professionals whose role only begins at the conference. While empirical evidence shows that programs like RESTORE can be highly successful at reducing recidivism and compensating victims, they are highly resource-dependent for each individual case. Such a resourceintensive process may be impossible in the Congo, given limited funding and the scope of the problem.

Even given adequate resources, this third way may be inadequate to promote justice and reconciliation in some situations. ${ }^{150}$ It may serve to undercut an already existing criminal justice system ${ }^{151}$ by making authorities complacent that something has happened. Amnesty International cautions that restorative justice can “complement” but

150 For example, as discussed infra, mediation has inherent drawbacks because of its assumptions of equality, and personalizes the violence between the perpetrator and victim, excluding considerations of community. See infra nn. __ Koss, Blame, Shame, supra note _, at 8.

${ }^{151}$ It’s In Our Hands, supra note _, at 99. 
not replace the criminal justice system; instead, “all perpetrators of crimes involving violations of human rights should be brought to justice.”152

Using the more traditional human rights framework is designed to result in national and international attention and public accountability, ${ }^{153}$ rather than treating sexual violence as a more private matter to be resolved locally. ${ }^{154}$ Traditional criminal justice prosecutions show the perpetrator, the victim, and their larger communities the seriousness of the crime that was committed. It may be that that the very structure of courtroom proceedings provides solace to the victim. ${ }^{155}$ In addition, advocates must examine the context in which the violence occurred, as well as the context in which the “solutions” are being proposed. ${ }^{156}$

Moreover, while repairing harmed lives is important, so too is preventing future harms. Sexual violence in an unsettled country requires forward-looking, as well as backward-looking, forms of justice. In situations of sexual violence, both criminal justice and restorative justice approaches are appropriate to handle the complexity of issues. Responding to sexual violence may require trials to provide public accountability,

\footnotetext{
${ }^{152} I d$.

153 In Our Hands, supra note _, at 101.

${ }^{154}$ In the United States, women's issues have typically been considered private matters. See Naomi Cahn, Family Law and Federalism, 79 IowA L. REV. 1073 (1994); Judith Resnik; "Naturally" Without Gender: Women, Jurisdiction, and the Federal Courts, 66 N.Y.U. L. Rev. 1682, 173550 (1991).

${ }^{155}$ Cf., Sally Engle Merry, Getting Justice and Getting Even (noting that simply going to court can make plaintiffs in civil cases feel supported, even if the judgment goes against them).

${ }_{156}$ Martha Minow suggests six different context-related questions in deciding between prosecution and truth commissions, although these questions are important in deciding how to proceed against war crimes perpetrators in other contexts as well. Between Vengeance and Forgiveness, supra note _, at 133-35. These questions include the involvement of international organizations, the seriousness with which nationbuilding is occurring, the identity of the perpetrators, and the allegiance of the government. For example, one question particularly relevant to the Congolese situation is: "Were the atrocities part of war, with human rights violations committed by all sides? Then some process of even-handed response would be crucial to the movement for international respect for human rights.” Id. at 134.
} 
but also reconstruction and reconciliation efforts that respond to the victims’ needs. ${ }^{157}$

Legal proceedings are critical for deterrence and retribution, but cannot comprehend the magnitude of the injustice, nor respond to the victim's injuries. ${ }^{158}$ Moreover, these are longer-term approaches. The Congo is not sufficiently stable to propose such solutions although, as discussed infra, the ongoing transition process provides opportunities to screen for perpetrators and begin to plan sanctions against the more egregious offenders.

c. Social Services Justice: Criminal and restorative justice solutions provide significant responses to gender-based violence, but they remain incomplete. A third kind of justice involves responding to the social, economic, and medical needs of the victims and potential victims. Like the best practices model for responding to victims of genderbased violence in the humanitarian community, this alternative vision of justice is multisectoral. ${ }^{159}$ It is not simply focused on perpetrators, or on guilt or innocence, but on the actual situation in which victims are left, on helping them move on with their lives and on recognizing that "political violence itself and the transitional period can often open up” opportunities for women - the so-called "gender dividend." ${ }^{160}$ And it is concerned about potential victims, about prevention as well as both short-term and longer term responses. One of its guiding principles is the importance of involving the victim and her community in developing programs to prevent and respond to the abuses. ${ }^{161}$

157 Drumbl, Toward a Criminology, supra note _, at 277; Jose Alvarez, Crimes of States/Crimes of Hate: Lessons from Rwanda, 24 YALE J. INTL. L. 365 (1999)

158 See Rosenblum, supra note _, at 93.

159 See Reproductive Health Response in Conflict Consortium, Gender-Based Violence Tools Manual for Assessment \& Program Design, Monitoring \& Evaluation in Conflict-Affected Settings 1, 37 (2003)

${ }^{160}$ Colleen Duggan and Adila Abusharaf, Reparation of Sexual Violence and Democratic Transition: In Search of Gender Justice, in REPAIRING THE PAST: REPARATIONS AND TRANSITIONS TO DEMOCRACY" , at 8 (forthcoming 2004)(manuscript on file with author)(need permission for all Duggan cites).

161 Guiding principles for responding to gender-based violence are concerned both with the development of programs, such as ensuring the full equality of men and women in program development, as well as with protection of victims and potential victims, such as guaranteeing confidentiality. UNHCR 
Establishing the procedures for restorative justice or civil and criminal trials are time-consuming; before these forms of justice arrive, women’s HIV may have become full-blown AIDS, their husbands may have married other women, they may be scared to sell goods at market or work in the fields. Social services justice focuses on the consequences and effects of the crime; because it is unrealistic for perpetrators to provide reparations directly to the victim, victims and communities need additional resources to heal the harm. The social services may be provided by the community, by the government, non-governmental organizations, multilateral institutions, or other donors. To achieve this justice requires a multisectoral approach that involves the community as well as health, legal, security, and the social services actors. ${ }^{162}$ Social services justice can take the form of medical kits to test for AIDS, establishing security patrols so that women can sell goods and produce at markets, or developing rape clinics which provide detraumatization services as well as legal counseling. For children whose education has been interrupted because their parents fear they will be attacked if they attend school, ${ }^{163}$ community watch committees can escort them to school. ${ }^{164}$ Some forms of social services justice are actually recognized in the Declaration on the Elimination of Violence Against Women, which urges states to provide services for women and their children, including “rehabilitation, assistance in child care and maintenance, treatment, counseling, and health and social services facilities and programmes . . . and should take all other

Guidelines, supra note _, at 27-28. Guiding principles are typically part of a baseline agreement amongst a coordinated group of organizations responding to situations of gender-based violence. Id. at 27.

162 See Ward, supra note _, at 11 ("best practices" for gender-based violence is now recognized as a "multisectoral model” which includes a variety of individuals, including teachers, traditional birth attendants, nurses, micro-credit banks, judges, police, and other military).

${ }_{163}$ See Pratt and Werchick, supra note _, at 13.

${ }^{164}$ Eagleton, supra note _ , notes that these patrols are already in effect in some parts of the Congo. 
appropriate measures to promote their safety and physical and psychological

rehabilitation.”165

Social service justice differs from restorative justice or the models of community

justice that are developing in the United States because it is not attached to a formal legal

proceeding, although it shares their focus on responding to crimes through involvement

beyond the perpetrator and victim. ${ }^{166}$ It is comparable to reparations, although

reparations typically take the form of government-transferred aid ${ }^{167}$ and involves the

provision of "material benefits for the devastation inflicted" based on a theory of

compensation. ${ }^{168}$ For example, in their nuanced discussion of reparation programs for

victims of sexual violence, Colleen Duggan and Adila Abusharaf discuss “national

reparations programs” which could provide remedies ranging from direct monetary

transfers to social services, such as providing scholarships for children of sexual violence

victims. ${ }^{169}$ Reparations are typically provided by the perpetrator, or a successor to the

perpetrator, to the victim. ${ }^{170}$ They involve an acknowledgement of guilt together with an

acceptance of responsibility. Social service justice (SSJ) may be administered and

\footnotetext{
165 Declaration, supra note _, at Art. 4(g).

166 The community justice approach involves both individualized justice and restorative justice, as well as partnerships with social service agencies and government groups to develop community-based responses to crime. See, e.g., Anthony C. Thompson, Courting Disorder: Some Thoughts on Community Courts, 10 Wash. U. J.L. \& Pol'y 63, 83-92 (2002); Jeffrey Fagan and Victoria Malkin, Problem Solving Courts and Therapeutic Jurisprudence: Theorizing Community Justice Through Community Courts, 30 FORDHAM URB. L.J. 897 (2003)

167 Perpetrators may also make reparations for their offenses.

168 Minow, Vengeance and Forgiveness, supra note _ , at 104.She provides examples of the types of reparations that witnesses before the South African TRC need, such as a death certificate, memorial parks named after an apartheid victim, or medical care. Id. at 105.

169 See Duggan, supra note _, at 28.

170 Reparations is a "tort-based mode of redress whereby a wrong-doing group accepts legal responsibility and compensates victims for the damage it inflicted on them.” William C. Bradford, Beyond Reparations: An American Indian Theory of Justice 1 (unpublished manuscript 2004)(available

at http://papers.ssrn.com/paper.taf?abstract id=515231 ). Professor Bradford notes the ongoing debate raging in the United States over reparations talk, particularly for descendants of African-American slaves, where opponents of reparation challenge the link between the contemporary status of blacks and historical
} 
funded by entities with no connection to the crime. While SSJ necessarily includes possible reparations programs as longer-term remedies, or as possibilities when the perpetrators are known and accept responsibility, it is also concerned with the more immediate, and often desperate, status of the victims. As such, social services justice refers to the range of potential services, social, economic, medical, that can be provided to victims both short and long term outside of the box holding perpetrator and victim, and beyond attempts to measure the specific losses caused by the violence. For example, it could provide protection for women who may not have directly experienced sexual violence themselves, but who live in continuing fear of it.

There are potential criticisms of social service justice that may undermine its effectiveness. First, social services justice may seek to ameliorate too many wrongs, some of which were not directly caused by the sexual violence; because of its breadth, like restorative justice, social services justice can be an expensive proposition in compensating the victim, her family, and her community. Second, because aspects of social services justice resemble development assistance, the social services may be emphasized at the expense of its justice and accountability aspects. Third, as with the other types of justice discussed, its effectiveness depends on sensitive implementation.

These are legitimate criticisms that must be addressed as the concept is more fully developed in theory and in practice. Assuring that the framing principle is social services in the context of responsibility and accountability, and that implementation can be carefully supervised to assure that neither victims nor perpetrators believe that the services provide an alternative to other forms of justice or a form of impunity, then social

injustices. Bridging the Color Line: The Power of African-American Reparations to Redirect America's Future. Note. 115 HARV. L. Rev. 1689 April 2002. 
services justice can aid transitional countries. Because it is based on the coordination and response of the different sectors concerned with prevention of, and response to, genderbased violence, it provides a useful model that can provide both immediate and long-term assistance.

\section{Principled responses}

Throughout this paper, I have been concerned with the practical realities of gender-based violence, with its causes and consequences, and with articulating different visions of justice to provide short and long term solutions to the complex situation of survivor, perpetrator, community, and country. Before returning to concrete recommendations, this section provides theoretical bases for choosing to engage in justice activities in a transitional society.

a. why act? Samantha Power has painstakingly documented the failure in U.S. response to a series of worldwide genocides, beginning with the 1915 Armenian genocide, and ending with more recent events in Rwanda and Bosnia. ${ }^{171}$ Se argues that American policymakers failed to act to stop genocide because they narrowly defined American interests, and tried to narrowly define the massacres so that the policymakers would not incur political costs through their failure to intervene. ${ }^{172}$ The reasons for acting to stop massive human rights abuses, she suggests are two: first, there is a moral duty to stop genocide, and second, Americans should act out of a sense of expanded selfinterest because genocide affects regional security, creates refugees, sends a signal of tolerance for cruelty, and ultimately expands. ${ }^{173}$ The reasons for acting in the aftermath

Power, A Problem from Hell, supra note _.

Power, supra note _, at 508.

Power, at 512-513. 
of conflicts are virtually identical. ${ }^{174}$ There is a moral imperative to help; but countries should also act out of enlightened, and long-term, self-interest.

b. How act? The fundamental principle of responding to gender-based sexual violence is to listen to what individual victims want. ${ }^{175}$ This first step involves hearing and documenting ${ }^{176}$ victims' stories and identifying the various consequences in their lives of the violence. It requires examining how women’s basic fundamental capabilities have been impaired. ${ }^{177}$

Because violence affects so many capabilities of the victims’ lives, the second principle requires looking both within the law and outside of the law in the effort to develop appropriate responses. In this connection, Martha Minow suggests three principles to guide the development of a victim-centered approach towards war crimes: first, restore community respect and integrity to the victim by, among other possibilities,

\footnotetext{
${ }^{174}$ The International Commission on Intervention and State Sovereignty has attempted to establish concrete parameters on both reacting (intervening) and rebuilding. See The Responsibility to Protect: Report of the International Commission on Intervention and State Sovereignty 2003 (avail. at http://www.dfaitmaeci.gc.ca/iciss-ciise/report-en.asp).

175 See Chinkin, supra note _, at 12 ("Survivors of rape must be provided the space to specify their own needs within the community”).

176 As discussed infra, documentation is critical because it allows for the identification of victims and perpetrator, and provides a record of crimes that may be used in prosecution or in other proceedings related to the transition process.

For further discussion of the capabilities approach, see AMARTYA SEN, DEVELOPMENT AS FreEdom (2000) and Women, Culture AND DEVElopment: A STUDY OF HuMAn CAPABILITIES (Martha C. Nussbaum and Jonathan Glover eds., 1995). The capabilities approach emphasizes the freedom of individuals to achieve, rather than measuring development as gross national product. See, e.g., MARTHA C. NussBaum, Introductory Essay, in WOMEN, CULTURE, AND DEVELOPMENT, supra, at 5.

The human capabilities approach, which is used by the United Nations Development Programme to measure people's abilities to perform certain basic functions in their countries, see Martha C. Nussbaum, Still Worthy of Praise, 111 HARV. L. REV. 1776, 1792 (1998), includes: "Bodily Health. Being able to have good health, including reproductive health; to be adequately nourished; to have adequate shelter. Bodily Integrity. Being able to move freely from place to place; to be secure against violent assault, including sexual assault and domestic violence; having opportunities for sexual satisfaction and for choice in matters of reproduction.” Martha C. Nussbaum, Human Rights Theory: Capabilities and Human Rights, 66 FORDHAM L. REV. 273, 287 (1997).

Bodily health and bodily integrity are two aspects of adolescent lives that are endangered through ignorance of reproductive issues and lack of access to reproductive products. As Amartya Sen points out:

[T] ]he "solution" to the population problem that seems to deserve the most attention involves a close connection between public policies that enhance social development and gender equity (particularly education, health care, and job opportunities for women), and individual responsibility of the family (through the decisional power of potential parents, particularly mothers). The effectiveness of this route lies in the close link between the well-being and agency of young women. As a result, the solution to the population problem calls for more responsibility and freedom, not less.

Amartya Sen, Fertility and Coercion, 63 U. CHI. L. REV. 1035, 1061 (1996).
} 
taking some action; second, listen to the victim's freely-expressed preferences and support her by, for example, providing social and economic help so that she can articulate her preferences; and third, develop viable alternatives to prosecution, such as truth commissions, so that restorative justice is a meaningful option. ${ }^{178}$ Victims may seek civil or criminal sanctions against their perpetrators, but they may also need seeds so that they can grow food for their families, more efficient stoves so that they need to go into the woods to collect less wood, or whistles so that they can call for help.

The third and final principle requires a long-term perspective that places individual victims into the larger contexts of their families, communities, and country. Each victim of gender-based violence deserves justice, but that justice must be defined by more than individual needs. Rape during armed conflict is both an individual and a group harm, a crime against the person and against her community and her gender. This final principle involves placing the victim within her differing communities; in turn, appropriate responses requiring balancing what the victim wants, what is in her best interests, what is in the best interests of her larger communities, and what will prevent future recurrences of violence. While retaining a victim focus, we must also develop principles to guide approaches to the community and the perpetrator, such as ensuring that the community and the perpetrator understand their responsibility for the violence, and helping the community develop its own responses to the violence and prevent future violence. The ICTR's landmark conviction of Akayesu, the first time that an international tribunal had found rape to be a form of genocide, and the ICTY's conviction of three Bosnian Serbs for rape and similar crimes, the first time that an international tribunal had heard charges based solely on crimes of gender-based violence, are critical

178 Id. at 980-81. 
steps in letting past and potential perpetrators know that they can be held accountable for such crimes. Protecting women who testify from retaliation, helping them mediate reintegration into their families and communities, are also critical steps in supporting victims and responding to their pain.

Taken together, all of these principles accomplish the following: help the victim to move on with her life, to reintegrate herself into her community and family, socially and economically, and develop measures that protect against recurrences of similar violence so that women feel secure.

While focusing on the victim and listening to her protects against imposing a Western, essentialist conception of justice on these transitional societies, post-conflict countries provide an opportunity to transform the underlying culture. Individual justice preferences may be distorted by repression and domination, ${ }^{179}$ so it is critical to place those preferences within a broader approach to human functioning in the post-conflict country. The transition process is focused on creating a democratic government for the country, of fostering a culture of democracy. ${ }^{180}$ As part of this process, there are public education campaigns to promote voting by men and women, and there are simultaneous efforts to change the laws. Part of the public education campaign concerns women's status and capability to participate in a democratic society (lessons like women's voice should be valued and they can make their own decisions re how to vote). Yet if women are to be considered fully capable members of society, education must help change the attitudes of both men and women, not just concerning participation in democracy, but

179 See Martha C. Nussbaum, Introduction, in Women, Culture, AND DeVElopment: A STUdy of Human CAPABILITIES 1, 5 (Martha Nussbaum and Jonathan Glover eds. 1995) 
also with respect to women’s rights to be free from violence in their homes. ${ }^{181}$ There must be “multiple remedies."182

Any resolutions will have both short and long-term components. Changing the internal justice system is a process that will require years; even developing an international court is a longer-term solution. Providing low-cost or free medical care and HIV testing is, on the other hand, a much more immediate solution.

\section{Recommendations}

To respond to the situation of victims and of their communities requires a multifaceted approach that focuses not just on the daily needs of the women and their families, nor even the long-term needs of their communities, but must also include recognition of the transition occurring throughout the country. In the Congo, as in other countries which have been subjected to internal wars, the international community and national government are involved in disarmament, demobilization, and rehabilitation (DDR) of former Congolese combatants and DDRRR (reinserting and resettling the non-Congolese combatants). A recent British government report identified DDR as “The first priority.”183 Virtually all members of civil society in the Congo, whether they are focused on democracy, sexual violence, or economic issues, agree that foreign troops must leave and stay out, domestic troops must be resettled, and a democratic government elected. The same energy that is involved in DDR for soldiers must also be used for

\footnotetext{
${ }^{180}$ As Professor Jennifer Widner notes, establishing "democratic political structures is the main strategy for sharing power in postconflict transitions.” Jennifer Widener, Courts and Democracy in Postconflict Transitions: A Social Scientist's Perspective on the African Case, 95 A.J.I.L. 64, 72 (2001).

181 As Susan Miller Okin powerfully argued 15 years ago, the public sphere and the family should utilize the same principles of justice. Susan Moller Okin, Justice, Gender, and the Family 25-43 (1989).

182 See Cynthia Grant Bowman, Theories of Domestic Violence in the African Context, 11 Am. U.J. Gender Soc. Pol'y \& L. 847863 (2003)(discussing need for multiple remedies to domestic violence in African countries).
} 
victims of sexual violence. Unfortunately, given women's status in society, given the tolerance for sexual violence, and given the high visibility of guns, but not of torn fistulas, that same energy is not yet forthcoming. ${ }^{184}$

A. Reintegration: Although reintegration in a post-conflict situation generally refers to reinsertion of former combatants into their home communities, it has a completely different meaning for victims of those combatants. For victims of gender-based sexual violence, reintegration has two aspects: first, victims must be accepted by their families, and second, victims must feel safe in their families and communities. The victims themselves want reintegration into their communities. They want their husbands, families, and neighbors to accept them, and for life to continue as though the sexual violence had never occurred. They are often less concerned with issues of justice, retribution, and impunity, and more concerned with food, shelter, and school fees for their children. Their husbands and fathers may want prosecution, but the women themselves may not want to undergo any additional trauma or reminders of their experiences - at least within the existing legal process. Women's responses may reflect their dependencies on their families and communities and a fear not only of proceeding against community members but also of retribution, or these responses may reflect a more empathetic, prospective approach to the violence committed against them. ${ }^{185}$

\footnotetext{
183 Break in the Clouds, supra note _, at 5.4.1.

${ }^{184}$ DDR focuses on combatants, who are typically male, while victims of sexual violence are overwhelmingly female. See Naomi Cahn, Responding to Victims of Gendered Violence (manuscript 2004)(discussing how financial allocations may reflect gender subordination). Not only are some combatants female, however, but also they may have female family members whose needs must be recognized by the DDR process. And, some sexual violence victims are male, as has been vividly illustrated by the revelations in 2004 of the American military's treatment of Iraqi prisoners. These realities should also help structure any justice programs.

${ }_{185}$ See Minow, Between Vengeance and Forgiveness, supra note _, at 978. As discussed below, it is crucial to respect victims' involvement in the prosecutions but there will be circumstances in which the victim's control cannot be total. See Cheryl Hanna, No-Drop Policies.
} 
One successful effort in Eastern Congo to reintegrate women has been through mediation by a respected community member, who may be a village elder, another woman, or a family member. By discussing the issues together, with a trusted third person, family members can accept the victim. Community education emphasizing that rape is not the victim's fault would also improve the situation, and a few high-level prosecutions might indicate that rape is a serious crime committed by a perpetrator, not welcomed by the victim.

As women return to their communities, they must also face their loss of livelihood and, in many cases, the loss of husbands or other family members. ${ }^{186}$ Their means of support, which, in the Congo, were already minimal, have been destroyed. The few farming implements have been pillaged and destroyed, food and seeds pillaged, and farming work has been disrupted. Consequently, they need educational and work programs, together with items as concrete as seeds, to help them become economically stable. If they owned land, notwithstanding gender-neutral inheritance laws, their husbands' relatives or other community members may have already taken control of it,. Overcoming customary inheritance practices and enforcing property laws will enable women to reclaim their farms and houses, although this cannot occur until their immediate environment is secured and there is a judiciary able to enforce existing inheritance laws.

Many women remain concerned about their future security. Not only are they survivors of past abuse, they are potential victims of future abuse. ${ }^{187}$ The instability that characterized the region for so many years has not dissipated, and large-scale conflict

186 After the Rwandan genocide, it was estimated that the Rwandan population was $70 \%$ female, and that $50 \%$ of families had female heads. Shattered Lives, supra note _. 
could easily recur. Women are still being raped, and are frightened that they will continue to be targets. They want better protection from future violence. Such protection involves strengthening local authorities, establishing safe havens, providing systems for emergency alerts. It also means letting women know where they can go in case they are subject to an attack, ${ }^{188}$ reassuring them that help will be available. The development of an independent media, an enterprise already occurring throughout most parts of the country with MONUC's Radio Okapi ${ }^{189}$, and the dissemination of information and trainings about tolerance may provide more secure future environments. ${ }^{190}$

As an example of the practical measures that would help women, consider two: giving women whistles, and providing more efficient stoves. Whistles, obviously, can provide protection by allowing women to alert anyone within hearing distance that they are in trouble and need help. ${ }^{191}$ Because most stoves in the Congo are wood or charcoalburning, more efficient stoves mean that women need to go to the forest to collect wood less frequently, thereby minimizing their exposure to potential victimization in the forest. Beyond reintegrating women into their communities, the processes of DDR and DDRRR must include sending foreign troops out of the country as well as providing

\footnotetext{
187 Jo Wells interview, 1/13/04.

${ }^{188}$ Beth Vann, Gender-Based Violence: Emerging Issues in Programs Serving Displaced Populations 10 (2003)( available at http://www.rhrc.org/resources/gbv/vann_toc.html)

189 See www.hirondelle.org. Even this ubiquitous radio station, with the full backing of the UN force in the Congo, does not reach isolated areas or many rural sections of the country.

190 See Martha Minow, The Work of Re-Membering: After Genocide and Mass Atrocity, 23 FoRDHAM INTL. L.J. 429, 437 (1999)(“After critical periods of violence, nongovernmental groups should muster not only humanitarian and peacekeeping aid, but also resource for media uncontrolled by factional forces. Attention to adolescents ... is especially crucial because they are likely targets of the hate-mobilizing efforts ... .efforts will also be needed to strengthen basic peace-keeping, law enforcement, judicial institutions, and infrastructure services”).

${ }^{191}$ In the US, there are various programs to give battered women used cell phones so that she can call for help if their abuser approaches them. See e.g., The Wireless Foundation, Call to Protect Campaign, at http://www.wirelessfoundation.org/CallToProtect/ (last visited Apr. 13, 2004); see also Lana Mobydeen, Note, Reach Out and Touch Someone: Cellular Phones Health, Safety and Reasonable Regulation, 16 J. L. \& HEALTH 373, 396 (2001-2002
} 
adequate supplies for Congolese troops seeking demobilization. And, during the transition process, as domestic troops are resettled through DDR, and foreign troops are repatriated through DDRRR, these repatriation programs must integrate the concerns of gender-based victims. DDR and DDRRR typically provide a package of goods, services, and money to soldiers agreeing to surrender their arms. While the plan in effect in the Congo, like many other DDR campaigns, precludes soldiers who are guilty of human rights abuses from receiving the package, the screening process must exclude soldiers guilty of gender-based violence. The phrasing in the government's DDR program is general, and subject to broad interpretation. ${ }^{192}$ Screening for gender-based violence will only happen if gender concerns are explicitly incorporated into the demobilization process so that the general term human rights abuses includes gender-based violence and if there is adequate documentation and verification so that the names of perpetrators are known. ${ }^{193}$ Once perpetrators have been identified, there are important choices concerning whether to imprison, prosecute, or simply segregate them from the communities. Working with victims is not sufficient, and it is critical to make decisions about how to treat identified perpetrators. ${ }^{194}$

\footnotetext{
${ }^{192}$ Gouvernement de la Republique Democratique du Congo, Programme National de Desarmement, Demobilisation et Reinsertion PNDDR 24. The package of services provided includes transportation costs and a security net of money. Id. at 41 .

193 This, in turn, requires delicate issues of confidentiality. Providing screeners with list of perpetrators risks the privacy of the victim. And, once someone has been screened out, he remains a problem; while some soldiers can be imprisoned for their crimes, the magnitude of the crimes suggests that there will be too many potential prisoners. Currently, there are over 90,000 alleged genocidaires incarcerated in Rwandan prisons. Jeevan Vasagar, Final Amnesty for perpetrators of Rwanda genocide, THE GuARDIAN, February 18, 2004. In February 2004, the Rwandan government offered a last chance for amnesty, and release from prison, if those alleged of participating in the genocide confessed their guilt. See id. Imprisoning only military commanders who encouraged gender-based violence, while simply not supplying the package of goods and services to other soldiers, might be appropriate.

194 See UNHCR Guidelines, supra note _, at 67. Alyson - please look at other DDR schemes (should be on-line) to see if gender is incorporated into DDR. In Liberia, women who are victims of "sexual and gender-based violence" are provided with counseling services as part of the DDR program. http://www.humanitarianinfo.org/liberia/coordination/sectoral/DDR/index.asp. However, other experts
} 
Creating a meaningful transitional government that can bring peace to the area is the solution most likely to end the ongoing sexual violence and provide the stability necessary to treat victims of rape. Sexual violence decreased when there was hope that the transitional government would be effective, but increased as the population became disillusioned that authorities were not taking control of the region. ${ }^{195}$

And fears about further conflict are well supported by research on the factors that are correlated with the outbreak of wars. Empirical research on the outbreak of conflict indicates that the most significant risk factors are low per capita income, low rates of economic growth, and dependence on commodity exports; and about one-half of those countries which have experienced a civil war are likely to experience another one within ten years. ${ }^{196}$ The Congo exhibits all of these factors. Although this does not mean that further conflict is inevitable, it serves as an impetus to developing safety plans for women who have already been sexually abused.

b. Health issues

Sexual violence in the Congo is a critical public health issue. All three aspects of what is traditionally defined as public health -- “ assessing health needs and problems, developing policies designed to address priority health issues; and assuring programs to

suggest that many DDR schemes do not meet the needs of female combatants, and thus do not adequately prepare communities for reintegration of ex-combatants. For example, many female combatants do not have a weapon to turn in, even though they were a part of the war effort. Under many DDR schemes, such women are excluded from the demobilization process, and all its services, because providers erroneously believe that they have nothing to 'demobilize'. Caroline Preston, "Rehabilitation Programs Reportedly Failing War-Affected Females”, April 5, 2004 http://www.unwire.org/UNWire/20040405/449_22484.asp Actually, there is some controversy on whether human rights abuses serve as a screen. 195 Pratt and Werchick, supra note _, at 7 (reporting that rapes appeared to decrease during the early months of the transition government, only to increase when the armed groups were not subject to local control).

196 Ian Bannon and Paul Collier, Natural Resources and Conflict: What We Can Do, in Natural Resources and Violent Conflict: Options and Answers 1, 3 (2003); Ken Menkhaus, A "Sudden Outbreak of Tranquility": Assessing the New Peace in Africa, 28 FlETCHER Forum ON WORLD AfFAIRS _ (May 2004); Naomi Cahn, Out Here in the Field, supra note 
implement strategic health goals" ${ }^{\text {197 }}$ - apply to constructing responses to gender-based sexual violence.

The first step is to collect information on the magnitude of the problem, the needs of victims, and existing capacity, ${ }^{198}$ while simultaneously beginning to establish special clinics and detraumatization. These centers could respond to gender-based violence victims with a variety of services as soon as a woman arrived, providing clothing and food, in addition to medical aid, such as pain relief and emergency contraception. Even without complete statistics or surveys on the situation, it is clear that women subjected to sexual violence have a series of health needs, ranging from HIV-tests and drugs to treatment for vaginal fistula to counseling. ${ }^{199}$ Most clinics are under-staffed and inadequately supplied; staff members lack training, including on how to protect the confidentiality of information about the victims, and other special resources for caring for sexual violence victims. While there are two hospitals in eastern Congo that are capable of treating severe cases of rape and injury, access is limited because of the number of beds, and because of the lack of information in rural areas about the services available. ${ }^{200}$ Although there are HIV-prevention medications that can be administered within 72 hours of a rape and that are $80 \%$ effective, the supply is inadequate, women rarely reach clinics

197 Jonathan Mann, et al, Health and Human Rights, in Health and Human Rights, supra note _, at 7, 12. ${ }^{198}$ See UNDP, Violences Sexuelles faites au Femmes et aux Enfants en RDC: Une initiative conjointe de prevention et de response aux besoins des victimes 22 (Kinshasa Nov. 2003)(on file with author). Collecting this information serves is useful for both public health and legal accountability reasons. See infra nn. _. On the other hand, information collection should not hinder other service-oriented efforts, and the two should be conducted together.

199 See, e.g., Interaction, Weaving Gender, supra note _, at 20 (emergency aid checklist for sexual violence survivors). On vaginal fistula, see Jackie Mertens, Congo Rape Victims Seek Solace, BBC News, 1/24/04 (available at http://news.bbc.co.uk/go/pr/fr/-/1/hi/world/africa/3426273.stm.

200 See Emily Wax, Brutal Legacy of Congo War: Extent of Violence Against Women Surfaces as Fighting Recedes, WASH. Post, Oct. 25, 200e, at A1; Crossette; Jan Goodwin, Silence=Rape, ThE NATION, March 8, $2004 \leftarrow$ need to short cite 
capable of administering the drugs within the requisite time period, and the course of treatment is long and onerous. ${ }^{201}$

Services for rape victims could be expanded through training additional physicians capable of handling these cases. ${ }^{202}$ To reduce other barriers to health care, such as lack of information and the difficulties of reaching medical care, larger clinics or nongovernmental organizations could develop mobile teams of health professionals specializing in rape-related services who could provide, among other things, training on physical and mental health issues as well as treatment in remote areas of rape survivors. ${ }^{203}$ These mobile teams could also support existing smaller medical clinics and birthing centers through training and supplies. In addition, local groups could publicize the visits of the teams, and the services provided.

Preventing pregnancy through an adequate supply of emergency contraceptives would help assuage some of the trauma for the women who arrived at clinics in time. ${ }^{204}$ Doctors Without Borders has made post-exposure HIV prophylaxis (PEP) available in its treatment of sexual violence victims in eastern Congo, although these are not a panacea for AIDS prevention. ${ }^{205}$

Some women are reluctant to be tested for HIV-AIDS, fearing that a positive outcome - or even the test itself - will result in further isolation and rejection, while others want the "clean bill of health" that a negative test will provide so that they can return to their husbands and families. Overcoming resistance to HIV testing and to

\footnotetext{
201 See Goodwin, supra note

See Pratt and Werchick, supra note _, at 22.

Pratt and Werchick, supra note _, at 10 (need permission).

Sexual Violence in Refugee Crises, supra note _, at 2.

205 In War as in Peace, supra note _ , at 9. Nonetheless, as discussed earlier, the drugs, while affordable, must be taken over a 4-week period, shortly after the violence and so cannot help many women for whom clinics are inaccessible.
} 
positive results requires work on a series of different levels, as illustrated by the Ugandan experience, where HIV-AIDS rates have been dramatically reduced. Studies of Uganda have identified several different elements as contributing to the overall success. First, the President personally led strong efforts to reduce the HIV infection rate, providing highlevels of political support throughout the government. Second, Uganda used grass-roots communication activities to promote AIDS awareness, including training teachers on how to teach about HIV in their curricula, and organizing religious leaders on how to handle HIV-related issues in education and counseling. The activities also emphasized the inclusion of women and youths in anti-AIDS efforts. For example, a statute requires that women constitute $1 / 3$ of the Parliament, and youth are also able to elect representatives. ${ }^{206}$ In addition, Uganda developed the first confidential voluntary counseling and testing program in Africa. ${ }^{207}$ Third, health programs, including condom promotion and projects focused on preventing sexually transmitted diseases, have also been important. Condom use for men who reported a non-regular sexual partner was $59 \%$, and for women, it was $38 \%$ in $2000 .{ }^{208}$ Overall, Uganda's success appears to rest on the personalization of the risk of HIV. ${ }^{209}$ Using small, personal networks to provide education as to the implications of HIV-AIDS, and as to the importance of accepting community members who may be HIV positive, could help women obtain testing and treatment, and aid in reintegrating them into their communities.

In addition to physical health, women's mental health has also been assaulted. There are few rape trauma centers, and one of the goals of a \$30 million proposal from

${ }^{208}$ Id. at 8.

209 Id. at 10. 
the UN is to establish centers for listening to victims and warning them. ${ }^{210}$ Health clinics could coordinate support groups so that women could discuss and develop best practices that help them handle the multiple effects of the violence. The groups could be selfperpetuating, so that they require minimal resources. As women in the groups became more secure, the groups could be expanded to address post-war trauma more generally among women, thereby decreasing the stigmatization of victims. ${ }^{211}$ Innovative drop-in centers, that integrated psychosocial and health support with survivor services or maternal care, could also expand to offer other services, such as micro-credit and small enterprise-building, as participants’ needs changed during the post-conflict period. ${ }^{212}$

\section{Community supports}

When civil authorities failed to respond to the crisis, it was local communities via churches, human rights and women's groups, and other, often indigenous, organizations that provided medical care and counseling to the abuse victims. ${ }^{213}$ These groups are continuing to offer as much care as they can, given financial constraints and ongoing fears of retaliation. The strength of the civil society response provides some recourse, and resources, within the victims' communities. Indigenous groups of women survivors of sexual violence have developed and, in the safer areas, have publicized their efforts via radio. $^{214}$

Within some communities, there are individuals who are highly respected and are able to mediate between victims and their families. The benefits of this form of

\footnotetext{
210 Violence, supra note _, at 28.

${ }^{211}$ Sexual Violence in Refugee Crises, supra note _, at3.

${ }^{212}$ For example, centers have combined nutritional information with micro-enterprise. Interaction, Weaving Gender in Disaster and Refugee Assistance: Report and field checklists 6-7 (2002)(available at www.interacton.org/caw/gender).

213 War Within a War, supra note __, at 76; Pratt and Werchick,

214 Pratt and Werchick, supra note _
} 
conferencing include countering "the helplessness induced by victimization ....

[providing the victim with] ritual face-to-face contact . . . under conditions attuned to protecting her safety, providing space for her story to be heard, and involving her as an active participant." ${ }^{\text {215 }}$ But there is a general lack of knowledge about sexual violence, and a mentality that blames the victim for what happened to her. The failure to prosecute, and the low status of women reinforce this mentality. Within some communities, restorative justice systems are developing indigenously and, in addition to providing mediation between victims and their families, are also mediating between victims and perpetrators. In one case, a perpetrator agreed to cover the victim's medical expenses as a result of mediation. ${ }^{216}$

But, as discussed above, reintegration for many women and their children is difficult, and will not occur without widespread education and other efforts designed to increase understanding of their situation. Public announcements, posters, radio, and television advertising should be targeted towards acceptance of sexually victimized women. Given that the community often shares the same belief systems concerning the role of women and the nature of sexual violence, education is critical to ensuring that restorative justice will be effective, rather than more traumatizing to the victim as she continues to experience the same rejections. Education must be directed at men, not just because they are the primary perpetrators of the violence, but also to help them respond

Koss, Blaming, Shaming, supra note _, at 9.

216 Marion Pratt and Leah Werchick, Sexual Terrorism: Rape as a Weapon of War in Eastern Democratic Republic of Congo 17 (March 2004). 
to situations of violence. ${ }^{217}$ Thus, community education is a critical component, not just long-term, but for an individual victim in an individual case. ${ }^{218}$

A second aspect of community support centers on issues of how to prevent future violence. Some women have developed their own strategies for safety, such as traveling in groups with other women, or asking men to accompany all-female groups. Yet even these methods are inadequate; one man who was traveling with a group of women was himself shot when he tried to protect one of the women from rape. ${ }^{219}$ An alternative strategy could involve community patrols, with the help of MONUC or another authority, so that women can sell their products at the market, chop wood for fires, and bring water to their homes, could help make women feel safe in their daily activities. ${ }^{220}$ Women and women's groups should be involved in designing procedures for greater security, ${ }^{221}$ and in implementing the programs, such as by becoming members of community patrols, or teaching others how to protect themselves.

These are short-term measures, however, and cannot substitute for the creation of legitimate local authorities, a respected, neutral judiciary, universal education, and enactment and enforcement of laws penalizing violence against women. ${ }^{222}$

c. The role of the law

Law is critical to defining the illegality of the conduct, to improving women's status, and to establishing democracy and accountability. Yet the "rule of law" is highly

\footnotetext{
${ }^{217}$ UNHCR, Sexual and Gender-Based Violence against Refugees, Returnees, and Internally Displaced Persons: Guidelines for prevention and Response ch. 3 at 6(2002)

218 See Quince Hopkins, e-mail, Jan. 28, 2004.

219 War Within a War, supra note _, at 75.

${ }^{220}$ USAID also recommends initiatives such as drilling wells closer to in habited areas. USAID public meeting with APPU.

${ }_{221}$ Women's Commission for Refugee Women and Children, Sexual Violence in Refugee Crises: A Synopsis of the UNHCR Guidelines for Prevention and Response 2 (available at www.womenscommission.org/special/guidelines/sexvio.html).
} 
questionable in transitional countries, which have none of the basic institutions that can help to establish and enforce the law. The law as written, and the law as it appears in the courts or on the streets, can differ dramatically. ${ }^{223}$ Throughout the reports of sexual violence is an acknowledgement of the lack of local authority to prevent the violence, and, as discussed earlier, the inability of the existing judicial system to process adequately the cases or to prevent retribution against the complainant and anyone who helps her. ${ }^{224}$ To file a complaint, the victim must pay $\$ 20,{ }^{225}$ an exorbitant amount in a country where the GNP is about $\$ 100$. One of the vice-presidents of the transitional government stated that the country must " "make reparations for and convict those guilty of rape." ${ }^{226}$ But there is no internal plan. In its recent report on the justice situation in the Congo, the UN monitoring force observed that there was a need to "restore" the rule of law and "create” appropriate institutions. ${ }^{227}$

As in other areas, the first step is an assessment of the existing situation, examining how sexual violence cases can be brought. Questions concerning how suspects are detained, where they are placed pending trial, how charges are made, the typical time

\footnotetext{
222 See USAID meeting. .

223 This is certainly true in the Congo. See also Stuart Cohn, Teaching in a Developing Country: Mistakes Made and Lessons Learned in Uganda, 48 J. LEGAL EDUC. 101, (1998). In preparing to teach a course on securities markets in Uganda, Professor Cohn discovered that "Nothing existed except the laws, a Capital Markets Authority that had no capital markets to regulate, and a stock exchange devoid of stock." Id. at 104. His advice to other teacher developing similar courses is not to assume that their students know the law; In Uganda, for example, copies of relevant statutes were simply not available in the numbers necessary for teaching in the classroom. Id. at 108.

224 For example, medical personnel from one of the two major hospitals that treat serious cases were asked to submit a medical report for a university student who had been violently raped and tortured by three army officers. Pole Institute, Une Plaie Encore Ouverte: La Problematique Des Violences Sexualles au Nord Kivu 24 (2004). The medical personnel were threatened because of their report, and felt quite scared; the case has been delayed. Id.

225 Herietiers, supra note _, at 6. Heritiers reports that some human rights organizations have helped in the filing of many cases, but local authorities claim that they cannot process the cases. Id. The organization knows of only one complaint that has actually resulted in incarceration for a soldier. Id. The soldier had raped a 7 year-old girl and was sentenced to 10 years.

226 DR Congo vows to punish rapists, supra note _ (citing remarks of Azarias Ruberwa).
} 
frame from arrest through outcome, reasons for the lack of prosecution, witness

protection programs, and training received by judges ${ }^{228}$ show the possibilities and problematics of bringing perpetrators to justice.

The need for a thorough analysis and reform is exemplified by women who have sought to bring the rapists to trial have themselves been further victimized by the legal system, which is in a state of disarray. There has been little investment in the national justice system, and court personnel have not been paid by the government for many years. ${ }^{229}$ Judges and prosecutors are appointed immediately upon graduation from law school, but receive no effective training for their positions; they are promoted based on their superiors' evaluation of their work. ${ }^{230}$ As one Congolese lawyer explained, “'Magistrates are not paid. They can’t refuse gifts ... women don't see the point in complaining. Even if they say something, what will change?’”231

Domestic rape law is inadequate, because it criminalizes only penetration of the vagina or anus with a penis. It does not cover penetration with an object. ${ }^{232}$ The ICTR defined rape much more broadly in the Akayesu case, noting that it included "acts which involve the insertion of objects and/or the use of bodily orifices not considered to be intrinsically sexual." ${ }^{233}$ Such a definition would have helped in a recent Congolese

\footnotetext{
${ }^{227}$ Progress Report of the Secretary-General on the Recommendations of the Security Council Mission to Central Africa, Jan. 20, 2004, S/2004/52.

${ }^{228}$ For a thorough checklist, see RHRC, Tools Manual, supra note _, at 33-35.

${ }^{229}$ Confronting Impunity, supra note _, at IV.

230 Id. at IV.b.

231 Rehn and Sirleaf, supra note _, at 97.

232 HRW, Confronting the Impunity, supra note _, at 9; Code penal, Arts. 167, 168, 170, 171.

${ }^{233}$ Akayesu Trial Chamber Judgment, at Para. 686.

The US Model Penal Code definition of rape does not include penetration with a foreign object, and is only limited to "[a] male who has sexual intercourse with a female not his wife" if the female is compelled in some way, is impaired, or unconscious. Model Penal Code $\S 213.1$ (ALI 1962). States have developed a variety of laws defining what will be prosecuted as rape. In New York, rape is defined as nonconsenting sexual intercourse, and does not include use of foreign objects. NY Penal Code $\S 130.35$. If a foreign object (or finger) is used in a sexual manner, causing physical injury to the non-consenting party,
} 
involving an eight-year old girl, where the defendant claimed that he had he used an object rather than his penis so that he would be acquitted of rape. ${ }^{234}$

Because the Congo is attempting the transition to a democracy, there are multiple opportunities for changing the legal system. Various non-governmental organizations have organized workshops to discuss law reform, involving people around the country from the community, human rights organizations, local and national government. ${ }^{235}$ As a result, the country's legislature has before it various laws that would conform the Congolese penal code to international law on war crimes and rape. ${ }^{236}$ While much of the legal reform is focused on ending impunity for perpetrators, reforms that would help victims include improving their status as full citizens, legalizing abortions (at a minimum for cases of rape), and protecting the confidentiality of information that survivors provide to medical and psychological care providers.

Once the law is changed, community education and know your rights campaigns become critical to informing victims about their rights and remedies. Encouraging victims to explore formal justice proceedings requires ensuring that they have sufficient

the perpetrator can be charged only with aggravated sexual abuse. NY Penal Code § 130.70. Similarly, in California, rape and penetration by a foreign object are distinct crimes. See West's Ann. Cal. Penal Code $\S$ 289 (2004). But see People v. Quintana, 108 Cal. Rptr. 2d 235, 89 Cal. App. 4th 1362 (App 1 Dist. 2001), which states "[s]ection 289 object penetration, in sum, is a form of rape" and emphasizes the intent of the sexual penetration statute was to put object penetration "on par" with rape. (emphasis in original). Additionally, the punishment for object penetration in California is the same for that of rape (3, 6, or 8 years, depending on other circumstances). Arkansas statutes, however, do define rape to include forcible penetration by a foreign instrument. Penetration with a foreign instrument "however slight" is considered “deviate sexual activity” West’s A.C.A. § 5-14-101. (Current through end of the 2003 Reg. Sess.). "A person commits rape if he or she engages in sexual intercourse or deviate sexual activity with another person by forcible compulsion.” A.C.A. § 5-14-103 (a)(1)(A)

${ }^{234}$ Jo Wells e-mail, 3/17/04 (need permission).

235 E.g., E-mail from John Talemwa, May, 26, 2004. There are organizations such as "Synergie des Femmes Pour Les Victimes des Violences Sexuelles" and "Coalition Contre Les Violences Sexuelles en Republique Democratique du Congo," as well as Global Rights (formerly the International Human Rights Law Group) which are involved in this issue.

${ }^{236}$ Given that the Congo is already a party to the relevant international conventions, these laws would simply conform domestic law to these documents. 
information about the adjudicatory process, their role, and the consequences, and ensuring that the law criminalizes the implicated behavior. The adult illiteracy rate is approximately $44 \%$ for women, and $19 \%$ for men ${ }^{237}$ indeed, less than two-thirds of all children are enrolled in secondary school. ${ }^{238}$ Written materials must be supplemented with counseling and media broadcasts; churches can be used to disseminate materials; information can be provided in birthing centers; the use of older women in the community and peer-to-peer counseling are examples of the types of creative programs necessary to change the mentality. ${ }^{239}$ Several non-governmental organizations have developed "know your rights" campaigns, which provide information about what women can do to report the crimes committed against them and seek justice.

But even in the United States, rape victims are reluctant to pursue litigation. ${ }^{240}$ The difficulties of prosecuting a rape case in the United States, of trying to establish nonconsent and penetration, where there are functioning police departments and forensic units, are magnified in a country without these resources. ${ }^{241}$

If women do go forward, and if the national justice system is completely restructured, or if some form of an international or regional court is established, and if the rape laws are rewritten, then there are a series of reforms that should be implemented to ensure that the legal system is prepared to handle these cases. The most basic

\footnotetext{
237 MICS at 83.

238 UNDP at 1.

239 The type of counseling will vary; some women will not want any, others may be comfortable with traditional practice. As Beth Vann warns, "[w]estern talk-therapy modes of counseling [may be] unfamiliar.” Vann, supra note _, at 72.

I have visited centers for street children in Kinshasa, Congo, which have little artwork except for a poster on avoiding pregnancy, so similar posters could be developed on sexual violence. See also Policy Paralysis, supra note _, at http://www.hrw.org/reports/2003/africa1203/10.htm\#_Toc56508504 (suggesting "nationwide awareness campaigns") .

${ }^{240}$ Koss, et al, supra note _, at 5.

241 Jo Wells e-mail, March 17, 2004.
} 
requirement is development of policies and protocols on gender-based violence cases, ranging from confidentiality guarantees to evidence collection to coordination with other actors. $^{242}$ Moreover, judges and court staff need training on issues of sexual violence, including its physical and psychological implications. ${ }^{243}$ A legal aid fund was recently established to provide training for judges, as well as for more basic needs, such as buying computers for the courtrooms. ${ }^{244}$

Second, victims and witnesses need to feel supported and safe throughout the legal system. Their identities may need to be protected from the public, they may need special forms of security, such as safe houses. ${ }^{245}$ to ensure their physical safety, and they may need support from specially-trained counselors. ${ }^{246}$ After some rape survivors testified in front of the ICTR, they received anonymous threats and other forms of harassment when they returned home, and they discovered that community members had detailed reports of their testimony. ${ }^{247}$ Congolese law has no special provisions that protect witnesses or that safeguard confidentiality. ${ }^{248}$ Courts could also provide health care services to ensure that victims remain sufficiently healthy to testify. ${ }^{249}$

\footnotetext{
242 Tools Manual, supra note _, at 48.

${ }^{243}$ See id (available at http://www.hrw.org/reports/2003/africa1203/10.htm\#_Toc56508504).

${ }^{244}$ UN Office for the Coordination of Humanitarian Affairs, DRC: Focus on rampant rape, Despite End of War, March 8, 2004 (avail. at http://www.irinnews.org/print.asp?ReportID=39912.

245 See Tools Manual, supra note _, at 49. These safe houses would be comparable to battered women's shelters, providing housing, food, and support in a confidential location.

${ }^{246} I d$. Other sources.

${ }^{247}$ Jefferson, In War as in Peace, supra note _, at 7.

248 War within a War, supra note _, at 81. Several US states have rape shield statutes that require hearings on possible inadmissible evidence (such as sexual history) to be held in camera, away from the press and the public. See COLO. REV. STAT. § 18-3-407(c) (1978). Importantly, however, if the evidence presented is found to be admissible, it will be presented in open court. See, e.g., 124 CONG. REC. H34,913 (daily ed. October 10, 1978) (statement of Rep. Mann in support of Federal Rule of Evidence 412): "[T]he in camera hearing ... protects the privacy of the rape victim in these instances when the court finds that evidence is inadmissible. Of course, if the court finds the evidence to be admissible, the evidence will be presented to the jury in open court.").

${ }^{249}$ In Rwanda, a women's organization is requesting AIDS-related drugs from the international tribunal to help keep witnesses alive. Rachel Rinaldo, Rwanda: Women Survivors of the Massacre Face a Grim Future, IPS-Inter-Press Service, April 6, 2004.
} 
Third, judicial systems should recruit more women as investigators, prosecutors, and judges. ${ }^{250}$ Women will not necessarily be better at or different from men in hearing and investigating these cases, but gender balance may make victims feel more comfortable and may provide alternative perspectives. Gender balance sends a signal that women's voices count. Fourth, mobile investigative units could collect evidence where the victims are, and could begin operating more quickly than formally established prosecutors' offices. ${ }^{251}$ In addition to cultural barriers, there are a series of other barriers to women reporting on their rapes, including their responsibility for child care and their inability to use family resources to travel. ${ }^{252}$ So long as it did not violate the victims' confidentiality, ${ }^{253}$ and did not lead perpetrators to believe that the departure of the team implied the departure of accountability, mobile teams could help establish the base for prosecutions and provide visible evidence of changes in prosecuting procedures.

And, the prosecutions must be weighed against an extremely "fragile" transition process $^{254}$ as the country tries to establish a democracy. The justice system must proceed "delicately" and carefully in choosing which perpetrators to punish. ${ }^{255}$ In the Congo, some of the potential defendants occupy positions of authority within the current somewhat fragile transitional government, ${ }^{256}$ and are likely to be on the ballot in the upcoming national elections. While they should not necessarily escape punishment,

\footnotetext{
250 Askin, Quest, supra note _, at 517-18; Ward, supra note _, at 14; Tools Manual, supra note _, at 48. Women may feel uncomfortable discussing sexual violence with a man, even if there is a two-person male-female interviewing team.

${ }^{251}$ HRW, Confronting Impunity, supra note _, at 8.

252 See Duggan, supra note _, at n. 48.

253 Some have suggested mobile courts, which would render judgments on site; victims might, however, be subject to retaliation when the court moves on, and there would have to be a guarantee that the mobile court's judgments would be respected by national and international tribunals. Pratt and Werchick, supra note _, at 18.

${ }^{254}$ A Break in the Clouds, Sec. 5.2, p. 10.
} 
prosecutors need to exercise discretion. Indeed, bringing several well-publicized cases will help show the end of impunity.

Rather than criminal lawsuits, victims could bring civil lawsuits seeking to hold perpetrators or the government accountable for the sexual violence, and seeking various forms of civil reparations. Catherine MacKinnon has brought a similar lawsuit in the former Yugoslavia. ${ }^{257}$ These lawsuits require that the defendant have financial assets that can be used to satisfy any judgment, and they may recreate the same traumas for the victim as would a criminal suit. ${ }^{258}$

Given the inadequacies of internal processes, even international tribunals may not provide a complete answer. The ICTR and ICTY, which have spent enormous amounts of money (the annual budgets for the two tribunals are in the $\$ 500$ million dollar range ${ }^{259}$ ), have issued comparatively few convictions ${ }^{260}$; symbolically, the existence of these tribunals is critical in showing that the international community is committed to prosecuting war crimes. Convictions in the international tribunals, and the recognition of rape in the statute establishing the International Criminal Court, similarly represent that rape is no longer a crime that will go unnoticed and unpunished. Yet such proceedings may not provide the most context-sensitive solutions to sexual violence against women because they represent one particular model of justice that is focused on

\footnotetext{
${ }^{255} I d$. This observation has been reiterated even more strongly in numerous personal interviews as well, although sources have declined to be identified.

256 Confronting Impunity, supra note _, at 3.

${ }^{258}$ See Hopkins, Applying Restorative Justice, supra note _, at 7 (draft).

${ }^{259}$ http://www.un.org/icty/glance/index.htm; http://ods-ddsny.un.org/doc/UNDOC/GEN/N03/509/70/PDF/N0350970.pdf?OpenElement http://ods-dds-ny.un.org/doc/UNDOC/GEN/N03/509/82/PDF/N0350982.pdf?OpenElement. The ICTY's 2004-05 budget was $\$ 271,854,600$.

${ }^{260}$ At the ICTR, there have been 18 convictions and one acquittal, although there are pending cases against 20 others, there are 22 people in custody awaiting trial, and 16 additional suspects who have been indicted.
} 
retribution and punishment. ${ }^{261}$ Moreover, the many difficulties faced by the international tribunals for the former Yugoslavia and Rwanda, ranging from procedural problems to issues of legitimacy with local communities, ${ }^{262}$ also vitiate against using them as the sole means of pursuing justice.

Outside of the formal justice system there are a series of quasi-legal proceedings that can be encouraged that will provide help in a variety of ways. First, as discussed above, the community mediations can be expanded to adjudicate between victims and perpetrators, and victims and their families. Second, even if prosecution does not happen tomorrow, it is important to document the sexual violence that has occurred not just (as discussed earlier) for public health reasons, but also for reasons of memory and potential future legal proceedings. ${ }^{263}$ Some local groups within the Congo have already started to document the sexual violence. ${ }^{264}$ Further documentation requires confidential systems of record-keeping; regardless of whether the perpetrators are ever publicly identified and brought to trial, telling their stories may help victims and creates public recognition of their harms. ${ }^{265}$ The simple act of record-keeping provides therapeutic benefits for individual victims, together with the community acknowledgement that the violence occurred. $^{266}$ Records can be stored at hospitals or with community leaders to safeguard their confidentiality. Simply telling their story to a sympathetic counselor, organizer, or

Rwanda: Focus on UN Tribunal, Feb. 3, 2004 (avail. at http: //www.npwj.org/modules. php?name=News\&file=article\&sid=1554).

261 See Mark Drumbl, Toward a Criminology of International Crime, 19 OHIO ST. J. DisP. RESOL. 263, 279-281.

262 See Drumbl, Criminology, supra note _ _, at 278-79 (2003); Minow, supra note _.

263 Pratt and Werchick, at 10.; o memory, see Minow, Breaking the Cycles, supra note _, at 28-29.

${ }^{264}$ In War as in Peace, supra note -_, at 9.

265 See Between Vengeance and Forgiveness, supra note _, at 120, 126.

266 An additional benefit is that it helps build civil society. If the records are collected by nongovernmental organizations, it helps those organizations to build their membership and credibility. 
court-appointed personnel can aid victims in finding justice and feeling vindicated. ${ }^{267}$

Using other women to conduct the interviews may help victims feel more comfortable in confiding the details of their experiences, but counselors may need to develop other methods for women who cannot even relate their stories to a woman interviewer. ${ }^{268}$ The confidentiality of the process may provide both protection and reassurance to women.

One woman, who had denounced her rapists, subsequently had her lips cut off to prevent any further talking; although initially reluctant, she indicated that she might consider going forward again with the right protections. ${ }^{269}$

Third, a truth and reconciliation commission provides opportunities to validate victims' stories, collect information about atrocities, and document the crimes that have occurred. Such a commission is actually mandated by the 2002 Congolese peace accord, and is supposed to consider various crimes committed between independence in 1960 to the establishment of the transitional government in $2003 .{ }^{270}$ Although the commission has been created formally, ${ }^{271}$ there are competing proposals under consideration by the Congolese legislature to govern its operations, and human rights observers are concerned that some of the members already appointed to the Commission may have themselves committed human rights violations. ${ }^{272}$ Moreover, one of the draft laws, which was developed by existing members of the Commission, does not include gender-based sexual

267 On the therapeutic benefits of narrative, see, e.g., Susan Bandes; Sally Engle Merry, Getting Justice and Getting Even.

268 See Duggan and Abusharaf, supra note _, at n. 68. They note that women must balance the possible gains from telling their stories against the drawbacks of coming forward and possibly harming their reputations. Id. at n. 70 .

269 See Pratt and Werchick, supra note

270 Confronting Impunity, supra note _, at 3.

271 Break in the Clouds, supra note _, at 4.5.

272 Confronting Impunity, supra note _ at 4. 
violence as one of the crimes on which testimony should be collected. ${ }^{273}$ For the Truth and Reconciliation Commission to be effective, it must be inclusive of gender-based violence. The Commission members must be respected and capable of leading a process that is fair and transparent. To create faith in its constituency, such a Commission could be headed by a consensus political figure,

Fourth, a program of national reparations provides another mechanism of responding to the harms inflicted. Reparations could take the form of financial compensation or restoring property or creating memorials. Reparations do, however, risk equating material goods with immaterial harms, and also creating false victims, who invent claims. On the other hand, the tangible nature of reparations make them symbolically and practically important to the recipients - where there is an ability to fund them and to identify appropriate recipients. ${ }^{274}$

E. International Actors

As the magnitude of the Congolese sexual violence becomes increasingly public, ${ }^{275}$ multilateral institutions and individual donor countries are developing programs to aid victims of sexual violence and to screen for human rights violators among the armed forces. But, while some donors attempt to coordinate with each other and with local groups, there needs to be improved communication among all of the groups involved. $^{276}$ International actors must work with each other, with local civil society and women's organizations, with religious institutions, and with the national and local

\footnotetext{
Id. at 4.

See Minow, From ..., supra note _, at 131-32.

275 In August 2003, actress Jessica Lange visited eastern Congo as a goodwill ambassador for the United Nations Children's Fund. Following her visit, Ms. Lange said the fighting in northeastern Congo has created "the worst humanitarian crisis on the planet". Jessica Lange Calls Attention to Congo, Sept. 10, 2003, AP ONLINE, 2003 WL 63460588.

${ }^{276}$ Coalition Contre Les Violences, supra note _, at 11.
} 
governments to prevent overlapping activities and to fund activities that are actually dealing directly with victims and their communities. ${ }^{277}$ Where the UN has deployed a peacekeeping force, as in the Congo, that force must be trained on sensitivity to gender issues. Many non-governmental organizations conduct trainings for their own employees and others on gender issues, and have developed codes of conduct concerning interactions between their field staff and the communities they are serving. ${ }^{278}$

\section{Conclusion}

Concepts of justice must be redefined to include non-legal remedies that "feel like” justice to victims. Sexual violence, like other crimes committed during armed conflict, affect individuals and communities in complex ways that require multi-layered responses. Focusing simply on prosecutions, on naming the sexual violence as a violation of international law, is critically important in gaining recognition of the significance of these crimes of gender, but does not necessarily respond to the actual needs of the victims. The response of local, national, and international actors must include legal and non-legal approaches that recognize the varying impacts of genderbased sexual violence during armed conflict. Restorative justice, which seeks to bring communities together after the perpetrator acknowledges guilt, provides an alternative model, albeit one that is within the legal system. Social service justice involves recognizing the concrete needs of victims. Social service justice means putting wells closer to their houses, providing seeds, establishing well-trained police, establishing rape trauma centers, supplying medicine is another alternative that provides justice outside of

\footnotetext{
277 The UNDP has developed a \$30 million proposal that funds many different levels of workshops, rather than funneling most of the money directly to groups working in the field. See UNDP, supra note
} 
the formal legal system. The three different forms of justice involve various responses that acknowledge the many levels on which sexual violence harms.

Yet providing justice to sexual violence victims also provides a method to transform the surrounding culture. Explicitly acknowledging the gendered nature of conflict can, somewhat paradoxically, help in mainstreaming gender issues into the transitional process. ${ }^{279}$ As women understand that their harms matter, and as they take the risks to make their claims known, they may be strengthened politically, economically, legally, and culturally.

Developing changes in laws and practices requires responding to opportunities. Countries in the post-conflict transition process provide multiple opportunities for transformation on many different levels, including local and national law, reintegration of soldiers and victims, changing attitudes towards basic health care, and improving women's status.

278 E.g., Ward, supra note __ Vann, supra note __ (model interagency manual includes specific guidelines re sensitivity to gender-based violence); UNHCR, App. 1.1, at 129 (core principles in a code of conduct provide that sexual abuse by workers form a basis for terminating employment).

279 See Duggan and Abusharaf (n. 9 - discussing gender dividend). 